\title{
Mechanistic Insights into MicroRNA-Mediated Gene Silencing
}

\author{
Thomas F. Duchaine ${ }^{1}$ and Marc R. Fabian ${ }^{2,3}$ \\ ${ }^{1}$ Department of Biochemistry \& Goodman Cancer Research Centre, McGill University, Montreal, \\ Quebec H3G 1Y6, Canada \\ ${ }^{2}$ Department of Oncology, McGill University, Montreal, Quebec H3G 1Y6, Canada \\ ${ }^{3}$ Lady Davis Institute, Jewish General Hospital, Montreal, Quebec H3T 1E2, Canada \\ Correspondence: thomas.duchaine@mcgill.ca; marc.fabian@mcgill.ca
}

MicroRNAs (miRNAs) posttranscriptionally regulate gene expression by repressing protein synthesis and exert a broad influence over development, physiology, adaptation, and disease. Over the past two decades, great strides have been made toward elucidating how miRNAs go about shutting down messenger RNA (mRNA) translation and promoting mRNA decay.

$\mathrm{H}$ ere, we review the mechanism of microRNA (miRNA)-mediated gene silencing and describe the most recent transformative discoveries. Focus is placed on miRNA target site recognition, and new insights into the structure of the miRNA-induced silencing complex (miRISC) and miRISC-interacting proteins. Finally, we discuss recent models that have been proposed regarding how the miRISC represses mRNA translation and promotes messenger RNA (mRNA) deadenylation and decay.

\section{THE FUNCTIONS OF miRNAs IN GENE NETWORKS}

miRNAs are small, 21-nucleotide (nt)-long noncoding RNAs that are encoded within the genomes of multicellular organisms and regulate gene expression. At the molecular level, miRNAs base-pair imperfectly with the $3^{\prime}$ untranslated regions ( $3^{\prime}$ UTRs) of targeted mRNAs, from where they engender mRNA translation inhibition and destabilization (Brennecke et al. 2005; Farh et al. 2005; Lim et al. 2005; Stark et al. 2005; Bartel 2009). The functions of miRNAs are thus defined through the identity of their targets. Consequently, the information an miRNA encodes takes on a physiological meaning only when considered as an integral part of gene-regulation networks. The functional impact of miRNAs is both broad and specific; more than 2000 miRNAs have been detected in the human transcriptome, and each miRNA specifically targets one to several dozen mRNAs (Krek et al. 2005; Lall et al. 2006; Baek et al. 2008; Friedman et al. 2009; Fang and Rajewsky 2011). It is estimated that more than $60 \%$ of human protein-coding transcripts are targeted by miRNAs (Friedman et al. 2009).

Editors: Michael B. Mathews, Nahum Sonenberg, and John W.B. Hershey

Additional Perspectives on Translation Mechanisms and Control available at www.cshperspectives.org

Copyright (C) 2019 Cold Spring Harbor Laboratory Press; all rights reserved; doi: 10.1101/cshperspect.a032771

Cite this article as Cold Spring Harb Perspect Biol 2019;11:a032771 
miRNAs play a dual role in gene-regulation networks, in shaping transcriptomes, and in controlling their output in protein synthesis. To perform these global functions, the expression and abundance of miRNAs, those of their target sites in mRNAs, their affinities, and their functional output through regulation of their effector machineries, have all been precisely tuned through evolution (Farh et al. 2005; Stark et al. 2005; Chen and Rajewsky 2006, 2007; Bartel 2009; Friedman et al. 2009). Variations on these parameters between biological conditions and cell types allow miRNAs to serve a diverse array of biological purposes (Ambros et al. 2003a; Ambros 2004; Chen and Rajewsky 2007; Bartel 2009; Sun and Lai 2013; Alberti and Cochella 2017). First, miRNAs can act as rheostats governing the expression of individual genes, by promoting partial but functionally significant repression. This function in fine-tuning gene expression appears pervasive in somatic cells, based on several genome-wide studies (Farh et al. 2005; Selbach et al. 2008; Guo et al. 2010; Fang and Rajewsky 2011). Second, miRNAs play important roles in making developmental decisions, such as steering a daughter cell away from its parental lineage (reviewed in Alberti and Cochella 2017). Examples include control of epidermal seam cell differentiation through regulation of lin- 41 mRNA by let-7 miRNA in Caenorhabditis elegans (Ecsedi et al. 2015), and the function of miR-155 in controlling macrophage maturation in mammals (Mann et al. 2010). Third, miRNAs can act in a concerted manner over multiple genes in a genetic cascade by toning down a group of genes in a pathway and/or by acting in feedback or feedforward loops. This can have deep impact at the cell, tissue, and organismal levels (Krek et al. 2005; Pelaez and Carthew 2012; Giri and Carthew 2014; Posadas and Carthew 2014; Alberti and Cochella 2017). A well-characterized example is the multilevel functions of lin-4 and let-7 miRNAs in the heterochronic cascade of C. elegans (Lee et al. 1993; Pasquinelli et al. 2000; Reinhart et al. 2000; Ambros 2011). In Drosophila, miR-7 provides robustness to developmental programs amid stochastic variations in endogenous and exogenous signals (Stark et al.
2005; Li et al. 2009; Alberti and Cochella 2017). Recent evidence highlights the importance of similar functions for miRNAs in controlling stress and aging (Emde and Hornstein 2014; Inukai et al. 2018). Fourth, miRNAs can drive the rapid turnover of large spans of the transcriptome in developmental or other physiological transitions. This is the case during the maternal-to-zygotic transition (MZT) in the zebrafish early embryo, wherein miR-430 instigates the rapid deadenylation and decay of hundreds of maternal mRNA targets (Giraldez et al. 2005, 2006).

Perhaps not surprising in light of their importance in gene-regulation networks, miRNAmRNA networks are often deregulated in human diseases ranging from heart disease (Xin et al. 2013) to various types of cancer (Croce and Calin 2005; He et al. 2005; Calin and Croce 2006). miRNA expression profiles provide signatures that inform on the pathogenic state of cells and tissues, on the origin of tumor outgrowth, and sometimes even on treatment prognostics (Iorio and Croce 2013; Sun and Lai 2013; Iorio and Croce 2017; Romano et al. 2017).

\section{MATURATION AND LOADING OF miRNAs ONTO ARGONAUTE PROTEINS}

The canonical biogenesis pathway of miRNAs (Fig. 1) involves a series of steps governed by the RNase III family enzymes Drosha and Dicer and their associated cofactors (see Ha and Kim 2014 for a review). miRNAs are derived from structured RNA polymerase II-generated primary miRNA transcripts (pri-miRNAs), which encode one or several precursor miRNAs (premiRNAs). Drosha and its double-stranded RNA (dsRNA)-binding protein cofactor DGCR8/ Pasha process pri-miRNAs and release $\sim 60$ - to 75-nt-long hairpin pre-miRNAs, which are exported into the cytoplasm (Lee et al. 2003; Carmell and Hannon 2004). Dicer and a family of dsRNA-binding protein cofactors further process the pre-miRNA yielding a 18- to 21-ntlong RNA duplex consisting of the passenger strand and the guide strand, which is also the mature miRNA (Bernstein et al. 2001; Grishok et al. 2001; Hutvágner et al. 2001; Ketting et al. 

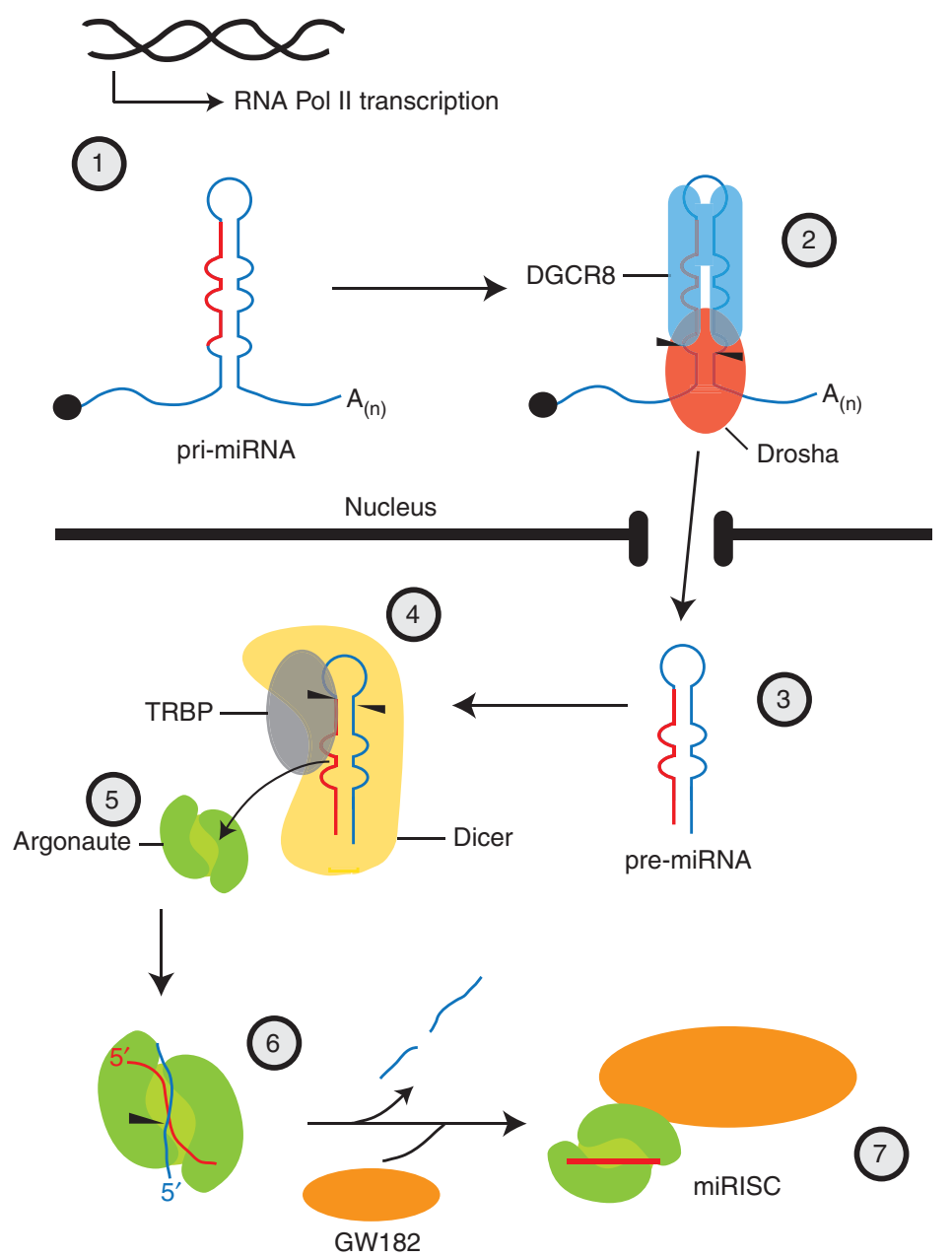

Figure 1. MicroRNA (miRNA) biogenesis and miRNA-induced silencing complex (miRISC) maturation. Primary miRNA (pri-miRNA) transcripts are generated by RNA polymerase II (1). Drosha and its double-stranded RNA (dsRNA)-binding protein cofactor DGCR8 bind to a pri-miRNA and release a $~ 60$ - to 75 -nt-long hairpin precursor (pre)-miRNA (2), which is exported from the nucleus to the cytoplasm (3). Dicer and a family of dsRNA-binding proteins (TRBPs in mammals) cleave the pre-miRNA (4), yielding an 18- to 21-nt-long RNA duplex consisting of the passenger strand (blue), and the guide strand (red), which is also the mature miRNA. The double-stranded miRNA duplex is loaded into an Argonaute protein (5), and the passenger strand is either cleaved by Argonaute slicing activity and released (6) or released independently of slicing when the two strands are mismatched. The mature single-stranded miRNA (red), Argonaute, and the Argonaute-interacting protein GW182 constitute the core components of miRISC (7).

2001; Knight and Bass 2001). Processing by Dicer and loading of the miRNA duplex into an Argonaute protein are closely coordinated processes and occur in a series of transitory (loading) complexes involving both proteins (Gregory et al. 2005; Maniataki and Mourelatos 2005; Kobayashi and Tomari 2016). Within the Argonaute, the
miRNA further matures as the passenger strand is either cleaved through the endonuclease activity of the Argonaute (an activity called slicing) and released, or released independently of slicing when the two strands are mismatched (Gregory et al. 2005; Matranga et al. 2005; Miyoshi et al. 2005; Park and Shin 2015). The fully mature, 


\section{T.F. Duchaine and M.R. Fabian}

single-stranded miRNA is stably embedded in the Argonaute (Fig. 2) wherein it carries out its function as a guide for silencing activities. Although some species including Drosophila and C. elegans rely on the sorting of miRNAs into functionally specialized Argonautes (DmAGO1 and ALG-1/2, respectively), mammalian species do not sort miRNAs into a specific Argonaute. miRNAs are thus found in association with HsAGO1-4, and HsAGO2 is shared between its siRNA and miRNA functions (Czech et al. 2009; Czech and Hannon 2011).
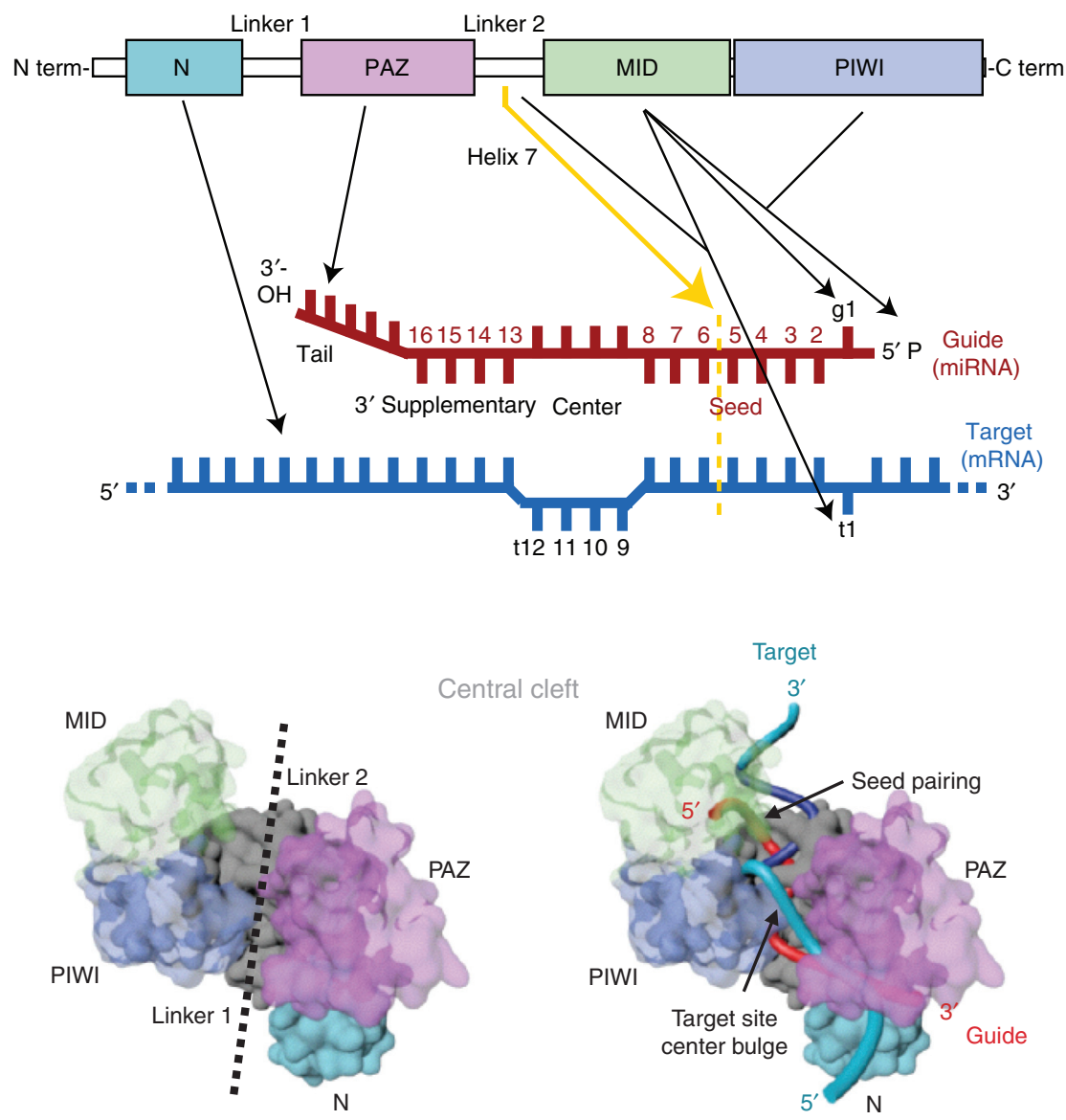

Figure 2. Structure and RNA interactions of Argonautes. (Top) The domain distribution and linkers 1 and 2 in the HsAGO2 primary structure are represented. Key interactions with the guide (the microRNA [miRNA]) and passenger (the target messenger RNA [mRNA site]) strands are indicated. The extensive interactions of linkers 1 and $2(\mathrm{~L} 1 / \mathrm{L} 2)$ with strand backbones in the central cleft are not indicated. Lines are connected when the interaction occurs at the interface between two domains (PIWI and MID for the guide $5^{\prime}$-phosphate, and MID and L2 for the target $\mathrm{t} 1$ nucleotide). Positioning of helix 7 (encoded in L2) in HsAGO2 and its blocking of nucleotides g6-8 of the seed are indicated (yellow arrow and dashed line) (Klum et al. 2017). (Middle) Linear representation of the base-pairing of an archetypal miRNA/mRNA pair. Proposed positioning of Seed, Center, $3^{\prime}$ Supplementary, and Tail nucleotides (Wee et al. 2012) are indicated. (Bottom) Structure of HsAGO2 bound to both guide miRNA (red strand), target RNA (blue strand) (Right model), and without RNA (Left model). Note that only the dark blue positions of the target RNA were observed in the structure. The path of the target strand in light blue is extrapolated. Target sequences opposite to Center nucleotides are bulged because of clashes within the cleft of HsAGO2 in those positions. See text for more details. (The structure [PDB 4W5O] was published in Schirle et al. 2014 and Sheu-Gruttadauria and MacRae 2017.) 


\section{THE MIRNA-INDUCED SILENCING COMPLEX}

The term RNA-induced silencing complex (RISC) was originally used to describe the assembly of the guide RNA with an Argonaute, the minimal components required to exert the slicing activity associated with RNA interference (RNAi) (Hammond et al. 2000; Hammond et al. 2001; Liu et al. 2004). In miRNA-mediated silencing, the physiological forms of RISC involve more components. The two core proteins of mammalian miRISC are one of the four Argonaute proteins (AGO1-4) and GW182 (glycinetryptophan $[\mathrm{GW}]$ repeat-containing protein of $182 \mathrm{kDa}$ ), which directly binds to Argonaute and is essential for recruiting effectors of miRNAmediated mRNA silencing (Fig. 1). For clarity, herein we distinguish the core components of miRISC (the miRNA, the Argonaute, and GW182 proteins) from proteins and complexes that effect silencing (the translation repression, deadenylation, decapping, and decay cofactors). The amino terminus of mammalian, zebrafish, and Drosophila GW182 proteins house numerous conserved GW, WG, or GWG repeats, which form AGO-interacting motifs that bind to two W-binding pockets in AGO proteins (BehmAnsmant et al. 2006a; El-Shami et al. 2007; Lian et al. 2009; Takimoto et al. 2009; Yao et al. 2011; Pfaff et al. 2013). A recent structural study showed that human GW182 contains three distinct AGO-interacting motifs (motif 1, motif 2, and the Argonaute hook) that bind with high affinity to both HsAGO1 and AGO2 (Elkayam et al. 2017), suggesting that multiple mRNAbound AGO proteins may recruit a single GW182 molecule to engender mRNA silencing.

\section{miRNA-ARGONAUTE INTERACTIONS IN TARGET RECOGNITION}

The functions of miRNAs are inseparable from the structure and interactions of Argonaute proteins (Fig. 2) (Wee et al. 2012; Chandradoss et al. 2015; Salomon et al. 2016; Sheu-Gruttadauria and MacRae 2017). An Argonaute protein folds in a bilobal structure (Song et al. 2004). Two lobes are formed by four distinct domains (amino terminal $[\mathrm{N}] / \mathrm{PAZ}$ and MID/PIWI) and are
Mechanisms of miRNA-Mediated Gene Silencing

separated by a central cleft wherein the guide RNA (the mature miRNA) and the target strand base-pair (Wang et al. 2008b). The guide RNA is held by the Argonaute in an extended conformation. The MID domain binds the $5^{\prime}$ terminal nucleotide of the miRNA (Boland et al. 2011; Frank et al. 2011), and the PAZ domain interacts with the very last $\left(3^{\prime}\right.$ end) nucleotides (Lingel et al. 2003, 2004; Song et al. 2003; Yan et al. 2003; Kidner and Martienssen 2004; Ma et al. 2004). Two linkers (L1 and L2) connect the lobes of the Argonaute and cradle the sugar-phosphate backbone of both guide and target RNAs (Wang et al. 2008a,b; Elkayam et al. 2012; Schirle and MacRae 2012). Argonaute shows sequence preferences for a $\mathrm{U}$ or $\mathrm{C}$ in the $5^{\prime}$-most nucleotide of the miRNA (position g1, see Fig. 2) and for an $\mathrm{A}$ in target sequences facing this position (t1). Binding to nucleotide recognition pockets of the MID domain prevents these nucleotides from base-pairing on target recognition (Schirle et al. 2015). The PIWI domain adopts an RNase $\mathrm{H}$ fold within Argonaute (Liu et al. 2004; Song et al. 2004) and carries the catalytic residues for the slicing activity, which is only permitted with extensive or complete base-pairing between the guide and the target RNAs. However, for the vast majority of animal miRNA-binding sites, one or more central residues of the miRNA (g9-g12) are mispaired (Fig. 2). Furthermore, genomic surveys indicate that pairing in these positions is not correlated with miRNA-mediated repression (Grimson et al. 2007). Slicing thus seems primarily to serve a biogenesis purpose in the miRNA pathway, in the cleavage and release of the passenger strand (Bouasker and Simard 2012; Jee et al. 2018). The PIWI domain also carries two tryptophan pockets in its outer structure, which are the binding sites for GW182 (Eulalio et al. 2008, 2009a; Schirle and MacRae 2012; Elkayam et al. 2017).

From within Argonaute, an miRNA is not free to hybridize with an mRNA the way a naked 21-nt RNA molecule would. Argonaute interactions profoundly modify miRNA hybridization kinetics by compartmentalizing the miRNA sequence into subdomains, namely, the $5^{\prime}$ anchor (g1), the seed (g2-g8), the center (g9-g12), the $3^{\prime}$ supplementary (g14-g16), and tail sequences 
(the $3^{\prime}$-most nucleotides) (Fig. 2) (Wee et al. 2012; Schirle et al. 2014; Salomon et al. 2016). Perhaps the most striking consequence of Argonaute interactions with the miRNA is the unique contribution of the seed nucleotides to target specificity (Lai 2002; Lewis et al. 2003, 2005; Brennecke et al. 2005; Farh et al. 2005). The importance of seed nucleotides became clear early on based on their conservation between paralogous and orthologous miRNA genes (Lagos-Quintana et al. 2001, 2003; Lau et al. 2001; Lee and Ambros 2001; Ambros et al. 2003b; Lim et al. 2003a,b). The functional significance of the seed has since been extensively supported with a conjuncture of conservation, unbiased forward genetics, in vivo and in vitro reporter assays, and structural biology (Lai 2002; Haley and Zamore 2004; Brennecke et al. 2005; Farh et al. 2005; Krek et al. 2005; Lewis et al. 2005; Lim et al. 2005). The positioning of the seed within Argonaute exposes the seed nucleotides (g2-g8) in the central cleft of the protein and enables their base-pairing with mRNAs. Argonaute-miRNA interactions benefit target recognition by preordering the nucleotides of the seed to defray the entropic cost of stacking bases in a readily hybridizable conformation (Nakanishi et al. 2012; Schirle and MacRae 2012; Schirle et al. 2014; Salomon et al. 2016). This accelerates base-pairing of seed nucleotides by $>20$-fold in comparison to free, disordered nucleic acid oligomers of the same length, to reach rates nearing the limits set by diffusion (Wee et al. 2012; Salomon et al. 2016). Seed pairing with a target site is a two-step process and involves the sequential base-pairing of nucleotides g2-g5 and g6-g8 (Wee et al. 2012; Schirle et al. 2014; Chandradoss et al. 2015; Sheu-Gruttadauria and MacRae 2017). Upon favorable pairing of g2-g5, the helix 7 of Argonaute (formed by $\mathrm{L} 2$ residues) is docked away from the guide RNA to give way and enable pairing of nucleotides g6-g8 (Klum et al. 2017). Binding of preordered g2-g5 is rate limiting for target recognition, whereas base-pairing of g6-g8 slows down release from a favorable target site (a pause called $d$ welling).

Another important impact of Argonaute structure on target site binding involves the interactions of the $3^{\prime}$ supplementary nucleotides with the $\mathrm{N}$ and PAZ domains. In target-free Argonaute, nucleotides g14-g18 of the miRNA thread through a narrow channel formed by the $\mathrm{N}$ and PAZ domains, wherein they are excluded from base-pairing (Schirle et al. 2014; SheuGruttadauria and MacRae 2017). Recent structures suggest a widening of the N-PAZ channel upon seed pairing to the target, possibly through conformational propagation involving helix 7 (Klum et al. 2017). Widening of the channel repositions the $3^{\prime}$ end of the miRNA and enables base-pairing of g14-g16, which is thought to nucleate an outward helix propagation and contribute to miRISC/target stabilization. Early genomic studies suggested that only about $5 \%$ of miRNA targets involve $3^{\prime}$ supplementary pairing of functional significance (Grimson et al. 2007), but this has remained a matter of debate. The most recent structures provide a conceptual framework to interpret studies which suggest that certain miRNAs may rely more on $3^{\prime}$ supplemental nucleotides for target recognition than others (Broughton et al. 2016; Wolter et al. 2017).

\section{FUNCTIONAL INTERACTIONS OF miRNAs AND miRISC IN 3'UTRs}

Within $3^{\prime}$ UTRs, miRNAs interact with a broad diversity of factors and mechanisms, which determine an mRNA's localization, stability, and translatability (see Mayr 2017 for a recent review). The regulatory functions of a $3^{\prime} U T R$ are dictated through the sequences it encodes, its folding structure, and its interactions with miRISC and RNA-binding proteins (RBPs). miRNA target recognition is sensitive to steric hindrance by $3^{\prime}$ UTR structures. Sites located near the stop codon (but outside the ribosome footprint) or closer to the poly(A) tail tend to have a more potent effect on silencing, presumably because they are positioned outside of the bulk structures of the $3^{\prime} \mathrm{UTR}$. Furthermore, miRNAbinding sites located near $\mathrm{A} / \mathrm{U}$-rich regions of $3^{\prime}$ UTRs are on average more potent, possibly because of the lower stability of the structures in such regions (Farh et al. 2005; Grimson et al. 2007).

Cooperative interactions between miRNAbinding sites in $3^{\prime}$ UTRs are also a major determinant of miRNA-mediated silencing. 
Genome-wide studies in mammals revealed early on that miRNA-binding sites that are located in close proximity to each other in a $3^{\prime}$ UTR elicit more potent silencing than sites separated by more than 50 nt (Grimson et al. 2007; Saetrom et al. 2007). In addition, tandem repeats of miRNA-binding sites located in $3^{\prime}$ UTRs of reporter mRNAs greatly sensitize artificial miRNA reporter assays (Pillai et al. 2005; Mathonnet et al. 2007; Fabian et al. 2009; Mayya and Duchaine 2015). miRNA-binding site cooperation appears to be a strict requirement in certain biological contexts such as the C. elegans embryo (Wu et al. 2010). Two non-mutually exclusive mechanisms have been described to explain miRNA-binding site cooperativity in $3^{\prime}$ UTRs. First, cooperative interactions between nearby binding sites can stabilize miRISC binding to the target mRNA (Broderick et al. 2011). Second, cooperation of multiple miRNA-binding sites can promote assembly of the effector machinery, through the recruitment of the CCR4-NOT deadenylase complex to target mRNAs (Flamand et al. 2017; Wu et al. 2017). A deeper understanding of the functional cooperation between miRNA-binding sites warrants further investigation.

Cooperative and competitive interactions between RBPs and miRISC in $3^{\prime}$ UTRs also profoundly modulate miRNA-mediated silencing (Bhattacharyya et al. 2006; Huang et al. 2007; Kedde et al. 2007; Elcheva et al. 2009; Takeda et al. 2009; Jafarifar et al. 2011; Kundu et al. 2012; Jens and Rajewsky 2015). For example, the Pumilio RBP can enable miRNA-mediated silencing by improving the accessibility of nearby miRNA-binding sites, presumably by destabilizing local RNA folding structures (Kedde et al. 2010). In an opposite scenario, the RBP Dead end 1 (Dnd1) binds to elements in uridine-rich sequences of $3^{\prime}$ UTRs located in close proximity to miRNA-binding sites and inhibits the association of miRISC (Kedde et al. 2007). Finally, several RBPs interact and recruit some of the same effector machineries to mRNAs, in particular, the CCR4-NOT complex. Clarifying how these RBPs functionally interact with miRISC should help to reliably predict the functional output of miRNA-binding sites.
Recently, an elegant single-molecule imaging system has been used to examine the dynamics of miRNA/Argonaute interactions on a 3'UTR mimic (Chandradoss et al. 2015). The results suggested that miRISC could slide along the $3^{\prime}$ UTR RNA between miRNA-binding sites. This sliding may represent a scanning activity of miRISC that could accelerate target recognition by reducing the collisions to a one-dimensional search along individual 3'UTRs. Even though enticing, the association rates observed were slower than the random-collision, near-diffusion rates observed with other assays (Wee et al. 2012; Salomon et al. 2016). It will be interesting to address the physiological implications of this phenomenon, and how sliding cooperates with or is counteracted by RBPs and $3^{\prime} \mathrm{UTR}$ folding structures.

\section{GW182-INTERACTING PROTEINS}

The carboxy-terminal region of GW182 proteins, termed the silencing domain, is required for GW182 to silence target mRNAs (Figs. 3 and 4). The silencing domain can be subdivided into a number of regions that are predicted to be unstructured, including the middle (Mid) and carboxy-terminal subdomains. These regions flank an RNA-recognition motif (RRM)-like domain, which does not bind RNA because of the presence of an additional $\alpha$ helix at its carboxyl terminus (Eulalio et al. 2009b). The Mid domain can be further subdivided into the M1 and M2 regions, which flank a poly(A)-binding protein (PABP)-interacting motif 2 (PAM2) (Roy et al. 2002). Although miRNA-loaded AGOs require GW182 to silence targeted mRNAs, GW182 alone is not sufficient. It is now well established that GW182 proteins engender miRNA-mediated gene silencing by interacting with a number of proteins, including $\mathrm{PABP}$, the poly $(\mathrm{A})$ nuclease (PAN)2-PAN3 and CCR4-NOT deadenylase complexes, and mRNA decapping factors.

\section{PABP}

In addition to binding to the mRNA $3^{\prime}$ poly(A) tail, PABP also interacts with a number of pro- 
T.F. Duchaine and M.R. Fabian

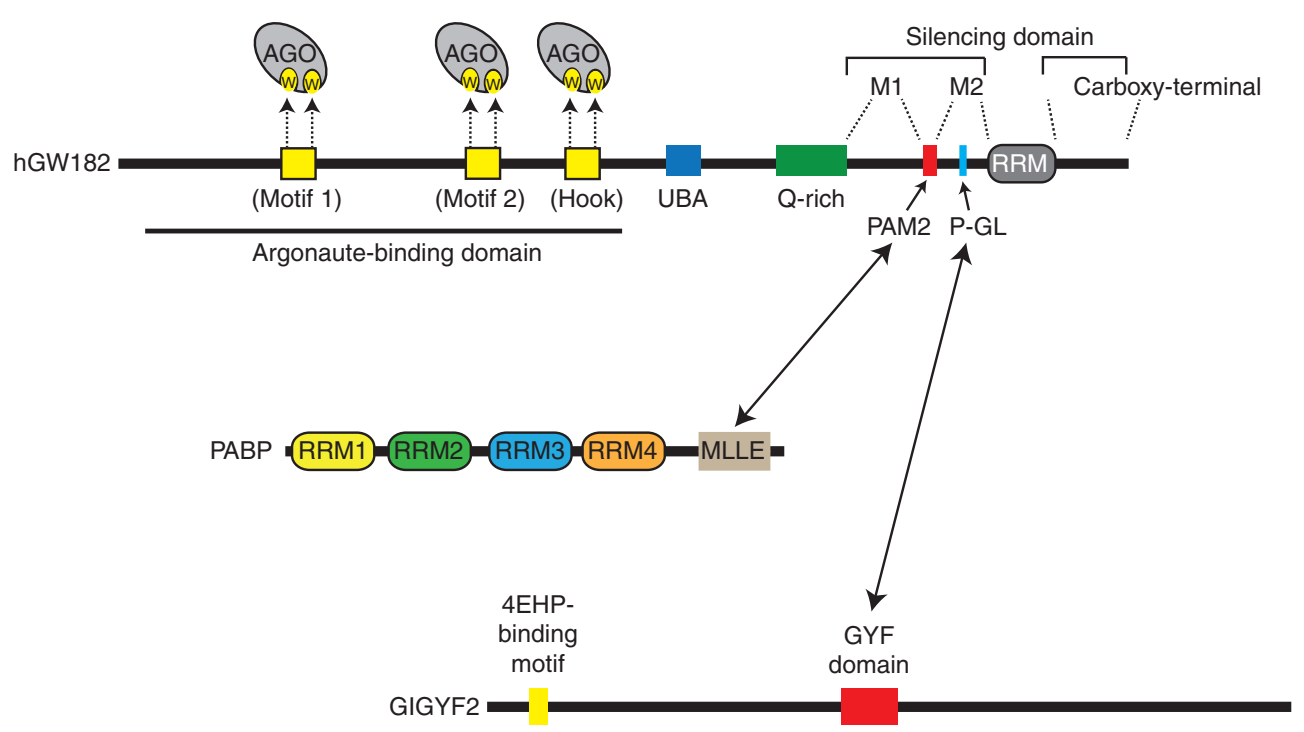

Figure 3. Schematic diagrams of glycine-tryptophan protein of $182 \mathrm{KDa}$ (GW182), poly(A)-binding protein (PABP), and GRB10-interacting GYF protein 2 (GIGYF2). The amino-terminal region of GW182 (the Argonaute-binding domain) contains a number of glycine-tryptophan $(\mathrm{GW})$ repeats, several of which form regions that bind AGO proteins (motif 1, motif 2, and the AGO hook). This region, in addition to the ubiquitinassociated (UBA) and glutamine-rich (Q-rich) domains, is responsible for targeting GW182 to processing $(\mathrm{P})$ bodies. The carboxy-terminal region of mammalian and insect GW182 proteins encompasses the silencing domain, which is the major effector domain by which GW182 engenders miRNA-mediated silencing. It is comprised of the M1 and M2 regions, the PABP association motif 2 (PAM2), the proline-rich PG-L motif, an RNA-recognition motif-like domain (RRM) that cannot bind RNA, and a carboxy-terminal domain. PABP domains include four functional RRMs and a conserved carboxy-terminal MLLE domain that directly binds the mammalian and Drosophila GW182 silencing domain via its PAM2 motif. Mammalian GIGYF2 interacts with the PG-L motif in the silencing domain of human GW182 via its GYF domain.

teins that regulate both mRNA translation and mRNA turnover (Derry et al. 2006; Smith et al. 2014). PABP stimulates cap-dependent mRNA translation via its interactions with the $5^{\prime}$ capassociated translation factor eukaryotic initiation factor (eIF)4G (Kahvejian et al. 2005). In contrast, PABP also associates with PAIP2, which inhibits translation by displacing PABP from the mRNA poly(A) tail (Khaleghpour et al. 2001). PABP can also regulate mRNA decay by directly interacting with the PAN3 subunit of the PAN2-PAN3 deadenylase complex, or the transducer of ERBB2 (Tob), which in turn recruits the CCR4-NOT deadenylase complex to target mRNAs (Siddiqui et al. 2007; Mauxion et al. 2009). PABP also directly binds to GW182 proteins via a stretch of residues in the GW182 carboxy-terminal silencing domain (Fig. 3). Originally referred to as a domain of unknown function (DUF), this region in the silencing domain is now classified as PABP-interacting motif 2 (PAM2) (Fabian et al. 2009; Jinek et al. 2010; Kozlov et al. 2010). Structurally, mammalian GW182 proteins bind PABP in a manner similar to that of other PABP-interacting proteins (i.e., PAN3, PAIP2, eRF3, and Tob) in that they interact with a PABP carboxy-terminal motif termed the MLLE domain (Jinek et al. 2010; Kozlov et al. 2010). The GW182 PAM2 motif is evolutionarily conserved in mammals, as well as in Drosophila where it also binds PABP. In contrast to mammalian and insect GW182 proteins, the C. elegans GW182 ortholog AIN1 lacks a PAM2 motif; nevertheless, it still interacts with $\mathrm{PABP}$, albeit via its amino-terminal RRMs (Kuzuoğlu-Öztürk et al. 2012). Several groups have reported that PABP enhances miRNA-mediated deadenylation in vitro (Fabi- 


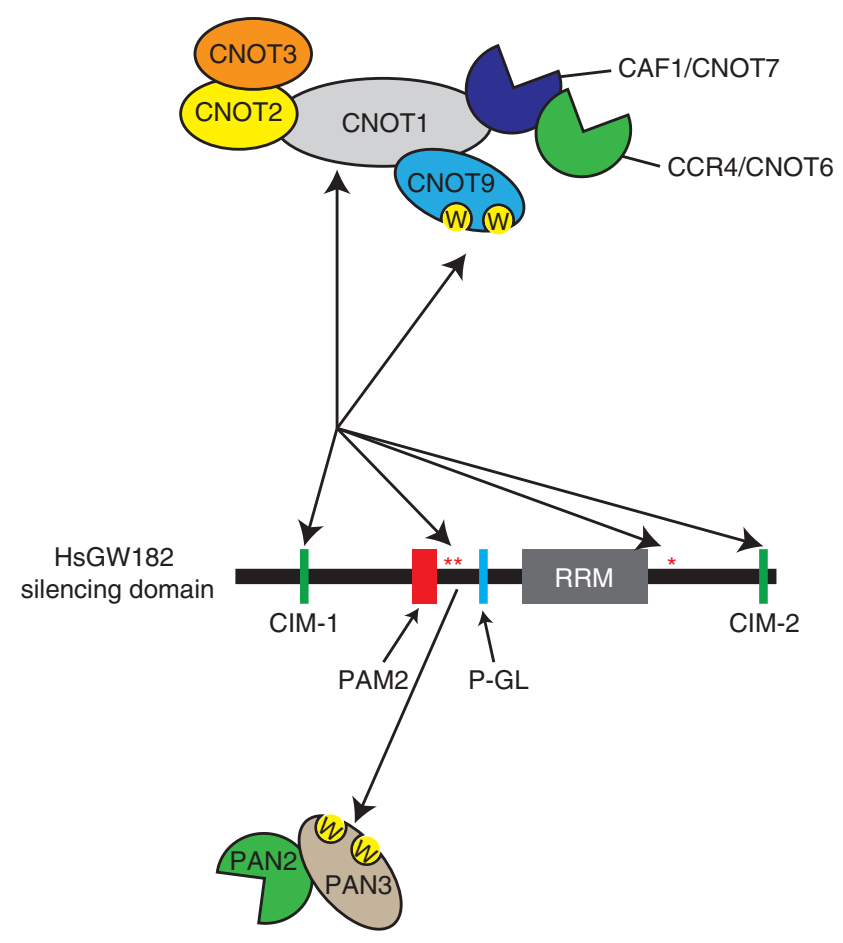

Figure 4. Schematic diagram of the human glycine-tryptophan protein of $182 \mathrm{KDa}$ (GW182) silencing domain and its interactions with the CCR4-NOT and PAN2-PAN3 deadenylase complexes. The GW182 silencing domain reportedly uses two CCR4-interaction motifs (CIM-1 and -2) and a number of conserved tryptophan residues in the M2 region and carboxy-terminal domain to interact with the CCR4-NOT complex. The silencing domain physically contacts both the CNOT1 subunit as well as CNOT9, the latter containing two tryptophan-binding pockets (denoted by W). The PAN3 subunit contains two tryptophan-binding pockets that directly bind to conserved tryptophan residues in the M2 region of the silencing domain. Conserved tryptophans in the silencing domain that have been reported to interact with PAN3 and CNOT subunits are denoted by red asterisks.

an et al. 2009; Flamand et al. 2016) and miRNAmediated silencing in cells (Huntzinger et al. 2010); however, not all groups have observed the PABP-GW182 interaction being required to promote miRNA-mediated repression (Fukaya and Tomari 2011). PABP and the poly(A) tail promote the association of the miRISC with targeted mRNAs (Moretti et al. 2012), suggesting that the PABP-GW182 interaction promotes GW182 recruitment to AGO-bound, miRNAtargeted mRNAs. Thus, it is possible that the PABP-GW182 interaction plays an important role in promoting miRNA-mediated silencing of mRNAs with long $3^{\prime} \mathrm{UTR}$ (Flamand et al. 2016), or with certain miRNA target sites that require $\mathrm{PABP}$ to enhance miRISC recruitment.

\section{CCR4-NOT and PAN2-PAN3 Deadenylase Complexes}

miRNAs promote the deadenylation of target mRNAs in a number of systems, including human and Drosophila cultured cells, zebrafish embryos, as well as mammalian, Drosophila, and C. elegans cell-free systems (Behm-Ansmant et al. 2006b; Giraldez et al. 2006; Wu et al. 2006; 2010; Wakiyama et al. 2007). miRNA-mediated deadenylation occurs as a biphasic event, which is mediated primarily by the CCR4-NOT deadenylase complex, as well as by the PAN2PAN3 deadenylase complex (Chen et al. 2009). An array of studies indicates that GW182 proteins act as evolutionarily conserved scaffolds 
that recruit the CCR4-NOT and PAN2-PAN3 deadenylation complexes to miRNA-targeted mRNAs (Fig. 4) (Braun et al. 2011; Chekulaeva et al. 2011; Fabian et al. 2011; Kuzuoğlu-Öztürk et al. 2012; Christie et al. 2013; Mauri et al. 2017; $\mathrm{Wu}$ et al. 2017). Structural and biochemical studies revealed that human GW182 proteins contact several CCR4-NOT complex subunits (Braun et al. 2011; Fabian et al. 2011; Chen et al. 2014; Mathys et al. 2014). The CNOT9 subunit uses two tryptophan-binding pockets to directly bind conserved tryptophans in the GW182 silencing domain (Chen et al. 2014; Mathys et al. 2014). In addition to binding CNOT9, the human GW182 silencing domain directly interacts with the CNOT1 subunit of the CCR4-NOT complex (Fabian et al. 2011). Thus, the GW182 silencing domain most likely makes multiple contacts with the CCR4-NOT complex, by contacting both the CNOT1 and CNOT9 subunits. The GW182 silencing domain also recruits the PAN2-PAN3 heterodimeric complex by interacting with PAN3. This has been reported to occur indirectly via PABP (Chekulaeva et al. 2011; Fabian et al. 2011) or direct binding through a tryptophan-containing pocket in the PAN3 kinase-like domain interacting with the M2 region of the GW182 silencing domain (Braun et al. 2011; Chekulaeva et al. 2011; Christie et al. 2013).

\section{GIGYF2}

PABP, the CCR4-NOT and PAN2-PAN3 deadenylase complexes are not the only proteins to directly interact with GW182. The GRB10-interacting GYF protein 2 (GIGYF2) was recently identified as a novel GW182 silencing domaininteracting protein by using a novel proximal biotinylation approach (Split-BioID) to search for miRISC-associating proteins in human cells (Schopp et al. 2017). Coimmunoprecipitation experiments and in vitro pulldowns using recombinant proteins showed that GIGYF2 directly binds to a conserved proline-rich P-GL motif in the Mid region of the GW182 silencing domain (Fig. 3). Knocking down GIGYF2 partially derepressed a tetracycline-inducible miRNA-targeted reporter in HeLa cells. As this derepression oc- curred at an early time point, before deadenylation (Bethune et al. 2012), GIGYF2 may play a role in translational repression. In keeping with these data, the P-GL motif contributes to tethered GW182-mediated repression in zebrafish embryos (Mishima et al. 2012). Interestingly, GIGYF2 directly binds to the $5^{\prime}$ cap-binding protein 4EHP/eIF4E2, which plays a role in translationally repressing select mRNAs (Rom et al. 1998; Cho et al. 2005; Morita et al. 2012; Peter et al. 2017). Moreover, GIGYF2 can silence a luciferase reporter mRNA when artificially tethered to its 3'UTR (Morita et al. 2012). Nevertheless, whereas these data suggest that GIGYF2 interacts with GW182, its exact role in miRNA-mediated repression has yet to be established.

Mechanistic Insights into miRNA-Mediated Translational Repression

Translation initiation begins with eIF4F complex binding to the mRNA $5^{\prime}$ cap structure. This complex is comprised of the cap-binding protein eIF4E, the eIF4A RNA helicase, and the scaffolding protein eIF4G, which interact with both eIF4E and eIF4A. Together, these translation initiation factors help recruit the $43 \mathrm{~S}$ preinitiation complex (PIC) to the mRNA $5^{\prime}$ terminus (Gingras et al. 1999; Merrick and Pavitt 2018). eIF4A helicase activity promotes ribosome subunit scanning by unwinding highly structured regions within mRNA $5^{\prime}$ UTRs.

A number of early studies suggested that miRNAs translationally repress targeted mRNAs by inhibiting cap-dependent translation at the initiation step, which is currently the most widely supported model (Fig. 5) (Humphreys et al. 2005; Pillai et al. 2005; Mathonnet et al. 2007; Thermann and Hentze 2007). miRNAs were also reported to repress translation postinitiation (i.e., by inhibiting ribosome elongation) (Olsen and Ambros 1999; Nottrott et al. 2006; Petersen et al. 2006). However, transcriptomewide ribosome profiling experiments, which measure translation efficiencies, do not detect any changes in ribosome elongation rates on miRNA-targeted mRNAs (Guo et al. 2010). Early reports that miRNAs inhibit translation are supported by investigations of the kinetics of 


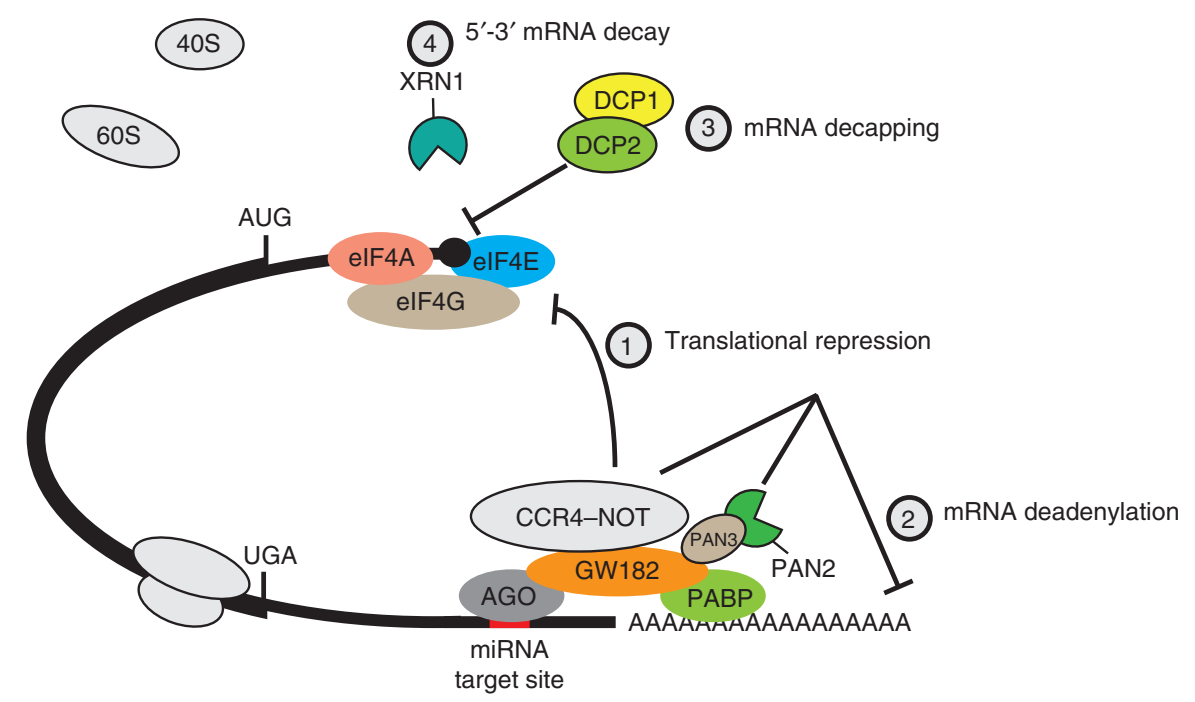

Figure 5. Model of microRNA (miRNA)-mediated gene silencing. Step 1, repression of cap-dependent translation via the CCR4-NOT complex: miRNA-induced silencing complex (miRISC) inhibits translation at the initiation step in a deadenylation-independent manner. Step 2, messenger RNA (mRNA) deadenylation: deadenylation is mediated by the CCR4-NOT complex and, to a lesser extent, the PAN2-PAN3 complex. Step 3, mRNA decapping: following deadenylation, the $5^{\prime}$ cap moiety, denoted by a black circle, is removed by the DCP1-DCP2 decapping complex. Step 4, mRNA decay: once the mRNA $5^{\prime}$ cap is hydrolyzed, the mRNA is degraded by the XRN1 $5^{\prime}-3^{\prime}$ exonuclease.

translational repression and mRNA deadenylation. Studies using fly and mouse cell-free extracts show that translational inhibition can be observed before detectable mRNA deadenylation (Fabian et al. 2009; Zdanowicz et al. 2009). miRNA-mediated translational repression before mRNA deadenylation was also reported in cells (Bethune et al. 2012; Djuranovic et al. 2012) and zebrafish embryos (Bazzini et al. 2012). Although these studies indicate that miRNAs repress mRNA translation, several global studies report that the majority of miRNA-mediated repression can be attributed to mRNA decay (Guo et al. 2010; Eichhorn et al. 2014). How miRNAs facilitate pure translational repression before mRNA destabilization remains a topic of current study, and several groups gained key insights in this field.

miRNA-Mediated Dissociation of Translation Initiation Factors from Target mRNAs

In keeping with repression of translation at the initiation step, several groups have reported that
miRNA-mediated silencing leads to the dissociation of translation initiation factors from targeted mRNAs. RNA pulldown experiments for miRNA- and GW182-targeted reporter mRNAs expressed in Drosophila S2 cells showed a decreased association of eIF4E, eIF4G, and PABP with miRNA-targeted mRNAs (Zekri et al. 2013). Similar results were observed in RNA immunoprecipitation experiments performed for miRNA targets in human embryonic kidney (HEK) 293 cells (Rissland et al. 2017) and cellfree extracts that recapitulate miRNA-mediated silencing in vitro (Moretti et al. 2012; Fukao et al. 2014). However, whereas deadenylation should remove PABP from a mRNA poly(A) tail, PABP is still displaced from deadenylation-resistant reporters that are targeted by either miRNAs or tethered GW182 (Zekri et al. 2013; Fukao et al. 2014). Nevertheless, miRNAs efficiently silenced a mRNA that lacked a poly(A) tail but instead had PABP artificially tethered to the mRNA $3^{\prime}$ end (Nishihara et al. 2013). Taken together, these data suggest that whereas miRNA-mediated dissociation of PABP may assist in translational 
repression, it is not the only mode by which miRNAs repress translation. Interestingly, knocking down the decapping factors DCP1 and EDC4 in tandem rescued the association of eIF4E with an miRNA-targeted reporter, even though eIF4G and PABP remained dissociated (Zekri et al. 2013). Thus, the miRNA-mediated silencing machinery may engender the dissociation of PABP and eIF4G before mRNA decapping, whereas eIF4E may be displaced as a result of $5^{\prime}$ cap hydrolysis. The linkages between mRNA translation initiation factors, decapping, and decay are further reviewed in this collection (Heck and Wilusz 2018).

\section{DDX6, 4E-T, and 4EHP}

Although the CCR4-NOT complex engenders deadenylation of miRNA targets, several studies showed that it can repress target mRNAs independent of its deadenylase activity (Cooke et al. 2010; Braun et al. 2011; Chekulaeva et al. 2011). In addition, tethering the CCR4-NOT complex can translationally repress deadenylation-resistant reporter mRNAs that contain a stretch of non-A nucleotides following the $3^{\prime}$ poly(A) tail, which suppresses mRNA deadenylation and decay (Kuzuoğlu-Öztürk et al. 2016). How does the CCR4-NOT complex repress mRNA translation? Several early studies showed that knocking down the translational repressor and decapping enhancer protein DDX6 in human cells, or its homolog in flies (Me31B), impairs miRNA-mediated silencing (Chu and Rana 2006; Eulalio et al. 2007). In addition, DDX6 directly binds the MIF4G (middle of eIF4G) domain of CNOT1, the central subunit of the CCR4NOT complex (Chen et al. 2014; Mathys et al. 2014; Rouya et al. 2014). Moreover, the interaction between DDX6 and CNOT1 enhances miRNA-mediated silencing (Chen et al. 2014; Mathys et al. 2014; Rouya et al. 2014), including silencing of miRNA-targeted reporters where deadenylation is prevented (Mathys et al. 2014; Kuzuoğlu-Öztürk et al. 2016). All in all, these data suggest that DDX6 binding to CNOT1 plays an important role in miRNA-mediated translational repression. Using in vitro ATPase assays, Mathys et al. (2014) showed that DDX6 ATPase is activated upon binding to CNOT1. Mutational analyses suggest that this plays a role in miRNAmediated silencing, albeit via an unknown mechanism.

In addition to binding CNOT1, DDX6 directly interacts with several proteins that inhibit translation and/or enhance mRNA decapping and decay. These include EDC3, LSM14, PATL1, and the eIF4E-binding protein, 4E-T, all of which bind to the DDX6 RecA-C domain in a mutually exclusive manner (Tritschler et al. 2009; Jonas and Izaurralde 2013; Sharif et al. 2013; Nishimura et al. 2015; Ozgur et al. 2015; Waghray et al. 2015). The crystal structure of the CNOT1/DDX6/4E-T complex (Ozgur et al. 2015) shows that DDX6, when directly bound to CNOT1, interacts with $4 \mathrm{E}-\mathrm{T}$ but cannot bind to other binding partners, including EDC3 and PATL1. Notwithstanding that PATL1 cannot directly interact with DDX6 when bound to CNOT1, PATL1 does interact with the CCR4NOT complex in a DDX6-independent manner (Haas et al. 2010; Ozgur et al. 2010).

How does 4E-T enhance miRNA-mediated gene silencing? $4 \mathrm{E}-\mathrm{T}$ contains an amino-terminal eIF4E-binding motif, as well as other regions that interact with DDX6, LSM14, PATL1, and UNR (Dostie et al. 2000; Nishimura et al. 2015; Kamenska et al. 2016). Knocking down 4E-T in human cell lines impairs miRNA-mediated silencing of reporter mRNAs (Kamenska et al. 2016; Chapat et al. 2017). Mechanistically, 4E$\mathrm{T}$ translationally represses reporter mRNAs when tethered to their $3^{\prime}$ UTRs in human cells and Xenopus oocytes (Kamenska et al. 2014; Waghray et al. 2015). Despite the ability of 4E$\mathrm{T}$ to compete with eIF4G for binding to eIF4E, tethered 4E-T represses mRNA translation in an eIF4E-independent manner (Kamenska et al. 2014; Waghray et al. 2015). Moreover, $4 \mathrm{E}-\mathrm{T}$ can also interact with the eIF4E homolog 4EHP (also known as eIF4E2), which represses mRNA translation. Recently, 4EHP has been implicated in miRNA-mediated translational repression, as knocking down 4EHP in mammalian cells partially derepressed miRNA-mediated silencing (Chapat et al. 2017; Chen and Gao 2017). 4EHP has also been reported to be essential in miR-145-mediated silencing of DUSP6 
mRNA, a repressor of ERK signaling (Jafarnejad et al. 2018). These data led to a model where a 4E-T/4EHP complex, recruited by CCR4-NOT, represses translation by competing with eIF4E for the $5^{\prime}$ cap (Fig. 6A). However, as $4 \mathrm{E}-\mathrm{T}$ can bind either eIF4E or 4EHP, it may translationally repress mRNAs whose $5^{\prime}$-cap structures are bound by either eIF4E or 4EHP (Fig. 6B). Although these studies suggest that $4 \mathrm{E}-\mathrm{T}$ assists in miRNA-mediated translational repression, 4E$\mathrm{T}$ has also been linked to enhancing mRNA decay of CCR4-NOT targets, including the let-7 miRNA target HMGA2 and reporter mRNAs targeted by the AU-rich element-binding protein tristetraprolin (TTP) (Ferraiuolo et al. 2005; Nishimura et al. 2015). Importantly, a $4 \mathrm{E}-\mathrm{T}$ mutant that cannot interact with eIF4E was defective in promoting the decay of TTP- and miRNA-targeted mRNAs in HeLa cells (Nishimura et al. 2015). Thus, 4E-T may play a role in promoting both early translational repression, as well as the decay of miRNA targets by bringing the CCR4-NOT complex and the decapping machinery into the vicinity of the mRNA $5^{\prime}$ terminus via its interaction with eIF4E or 4EHP.

\section{A Link between the CCR4-NOT Complex and eIF4A}

As previously mentioned, the eIF4A translation initiation factor is an ATP-dependent RNA helicase that assists $43 \mathrm{~S}$ ribosomal scanning by unwinding secondary structures in the mRNA 5'UTR (Sonenberg and Hinnebusch 2009; Merrick and Pavitt 2018). The CCR4-NOT complex was reported to recruit eIF4A2, a vertebratespecific paralog of eIF4A, and this interaction translationally represses miRNA targets by impairing 43S ribosomal subunit scanning (Meijer et al. 2013). However, these data have been contested in several follow-up studies (Galicia-Vazquez et al. 2015; Kuzuoğlu-Öztürk et al. 2016), one reporting that a human cell line where eIF4A2 has been knocked out displays no noticeable defects in silencing by miRNAs. Although a model wherein miRISC specifically interacts with eIF4A2 to silence target mRNAs has been challenged, two independent studies
Mechanisms of miRNA-Mediated Gene Silencing

reported that miRNA-mediated translational repression targets eIF4A (Fukao et al. 2014; Fukaya et al. 2014). Knocking down eIF4A in D. melanogaster $\mathrm{S} 2$ cells impairs miRNA-mediated translational repression. Moreover, RNA pulldown and chemical cross-linking experiments in human and fly cell-free extracts that recapitulate miRNA-mediated silencing show that eIF4A is displaced from miRNA-targeted reporter mRNAs (Fukao et al. 2014; Fukaya et al. 2014). Furthermore, the addition of $\mathrm{HuD}$, an eIF4A-binding protein that stimulates translation, to a cell-free extract impairs miRNA-mediated translational repression, whereas a $\mathrm{HuD}$ mutant that cannot bind eIF4A does not (Fukao et al. 2014). Taken together, these data suggest that the miRNA machinery interfaces with eIF4A (either directly or indirectly) to repress translation.

In keeping with a link between miRNA-mediated silencing and eIF4A helicase activity, it has been reported that miRNA reporters harboring unstructured $5^{\prime} \mathrm{UTR}$ are refractory to miRNA-mediated silencing in a rabbit reticulocyte in vitro translation system (Ricci et al. 2013). However, a recent study (Kuzuoğlu-Öztürk et al. 2016) did not come to the same conclusion. Efficient miRNA-mediated translational repression was observed with luciferase reporters containing short $(<10 \mathrm{nt}) 5^{\prime} \mathrm{UTRs}$, including the translation initiator of short $5^{\prime}$ UTR (TISU) that directs cap-dependent translation via a scanning-independent mechanism (Elfakess et al. 2011; Kwan and Thompson 2018). Both the miRISC and the CCR4-NOT complex efficiently translationally repressed these reporters, suggesting that miRNAs inhibit translation initiation at a step other than $43 \mathrm{~S}$ ribosomal subunit scanning. In addition, varying the $5^{\prime}$ secondary structure had no noticeable impact on translational repression, again demonstrating that miRNA-mediated silencing does not seem to require eIF4A helicase activity (Kuzuoğlu-Öztürk et al. 2016). Although these data indicate that eIF4A helicase activity is not the major target of the miRNA machinery, they do suggest that eIF4A plays an important role in miRNA-mediated translational repression. One possibility is that miRISC-associated factors, including 
T.F. Duchaine and M.R. Fabian

A
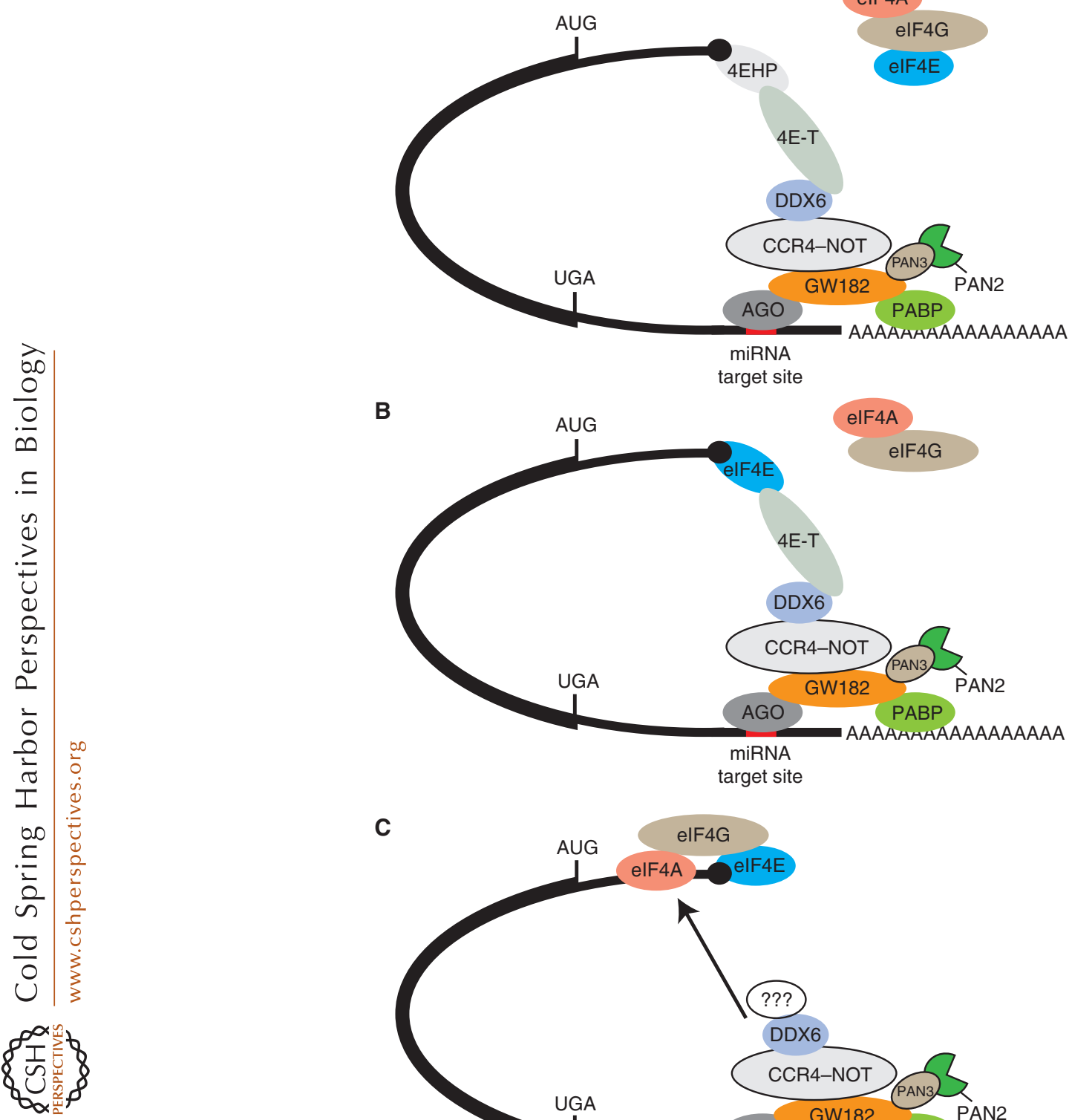

B

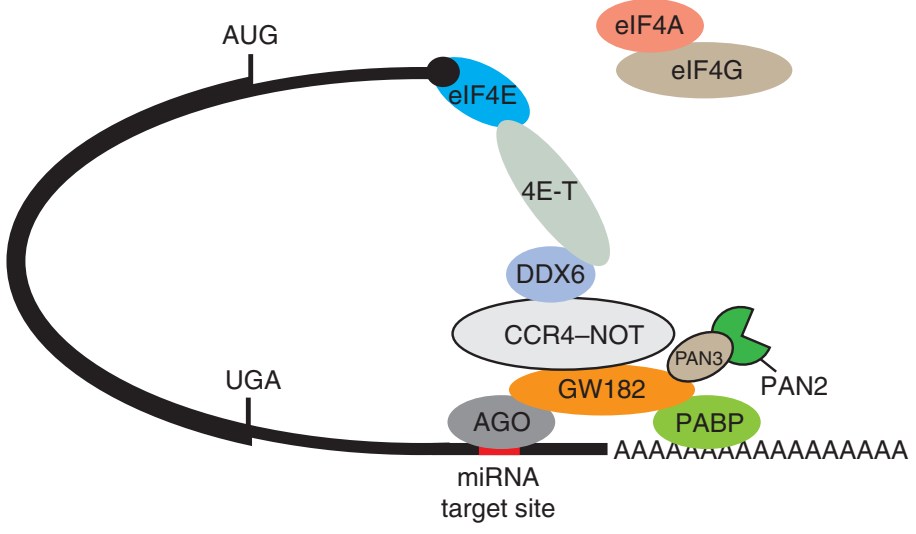

C

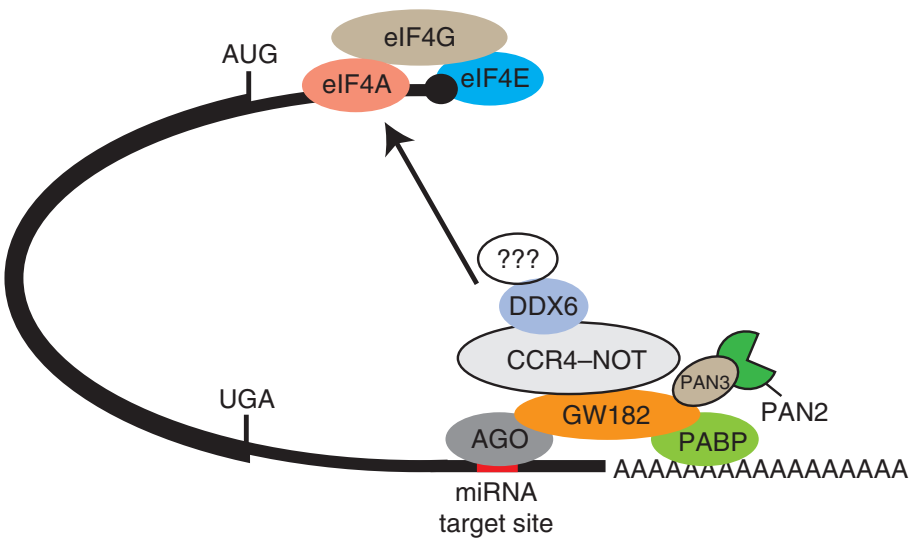

Figure 6. Models for microRNA (miRNA)-mediated translational repression. It is important to note that these models are not mutually exclusive. $(A)$ The CCR4-NOT/DDX6 complex recruits 4E-T and 4EHP, the latter functioning to displace eukaryotic initiation factor (eIF)4E from the cap structure and associated translation factors (i.e., eIF4G and eIF4A). (B) The CCR4-NOT/DDX6 complex recruits 4E-T, which binds to eIF4E thereby displacing eIF4G. (C) The CCR4-NOT/DDX6 complex, potentially with unknown binding partners (denoted by ???), interacts with eIF4A leading to inhibition of translation initiation. 
DDX6, may inhibit translation initiation by physically interacting with eIF4A, rather than by specifically impairing eIF4A helicase activity (Fig. 6C). However, this model remains to be directly tested.

\section{CONCLUSIONS AND FUTURE PERSPECTIVES}

These are exciting times in the field of miRNAmediated silencing. Progress is being made with respect to how the miRISC identifies and interacts with target sites, and on how its interactions direct mRNA translation repression, deadenylation, and decay. Parameters such as cellular miRNA concentrations, their stoichiometric ratio with their mRNA targets, and affinities for target sites are being examined in a quantitative manner. Genome-wide studies have yielded critical information regarding miRNA-mRNA 3'UTR networks. The recent development of libraries capturing the poly(A) tail status in transcriptomes is particularly promising (Subtelny et al. 2014; Rabani et al. 2017; Rissland et al. 2017; Yartseva et al. 2017). Emerging quantitative single-molecule imaging methods consolidate previous models and unveil properties of miRISC that had been missed through batch experiments. Several key aspects of miRNA-mediated silencing remain to be elucidated, however. miRISC recruits the CCR4-NOT deadenylase complex to repress mRNA translation before initiating mRNA deadenylation and decay, but it remains to be established how the CCR4-NOT complex and associated factors bring this about. In addition, whereas several studies indicate that $5^{\prime}$ cap-associated translation initiation factors such as eIF4G and eIF4A are displaced from miRNA-targeted mRNAs before, or in the absence of, mRNA destabilization, the mechanistic underpinnings of this observation remain unknown. Cooperative and/or competitive interplay between RBPs such as TTP and Pumilio, miRISC, and the CCR4-NOT complex also warrants further resolution. Perhaps progress on those topics will explain some of the lingering disparities on the relative contributions of miRNA in driving mRNA translation repression, deadenylation, decapping, and decay.
These topics remain at the front line of current miRNA biology.

\section{ACKNOWLEDGMENTS}

We apologize for any directly related work that we have not cited in this review. We thank Dr. Noriko Uetani for her assistance with the graphical design of Figure 2. This work is supported by Canadian Institute of Health Research (CIHR) grants to T.F.D. (MOP-123352) and M.R.F. (MOP-130425), a Natural Sciences and Engineering Research Council of Canada (NSERC) Discovery grant to M.R.F. (RGPIN-201503712), Fonds de recherché du Québec-Santé (FRQS) Chercheur-Boursier Senior salary award to T.F.D. and Junior 1 salary award to M.R.F., and CIHR New Investigator award to M.R.F.

\section{REFERENCES}

* Reference is also in this collection.

Alberti C, Cochella L. 2017. A framework for understanding the roles of miRNAs in animal development. Development (Cambridge, England) 144: 2548-2559.

Ambros V. 2004. The functions of animal microRNAs. Nature 431: 350-355.

Ambros V. 2011. MicroRNAs and developmental timing. Curr Opin Genet Dev 21: 511-517.

Ambros V, Bartel B, Bartel DP, Burge CB, Carrington JC, Chen X, Dreyfuss G, Eddy SR, Griffiths-Jones S, Marshall $\mathrm{M}$, et al. 2003a. A uniform system for microRNA annotation. RNA 9: 277-279.

Ambros V, Lee RC, Lavanway A, Williams PT, Jewell D. 2003b. MicroRNAs and other tiny endogenous RNAs in C. elegans. Curr Biol 13: 807-818.

Baek D, Villen J, Shin C, Camargo FD, Gygi SP, Bartel DP. 2008. The impact of microRNAs on protein output. $\mathrm{Na}$ ture 455: 64-71.

Bartel DP. 2009. MicroRNAs: Target recognition and regulatory functions. Cell 136: 215-233.

Bazzini AA, Lee MT, Giraldez AJ. 2012. Ribosome profiling shows that mir-430 reduces translation before causing mRNA decay in zebrafish. Science 336: 233-237.

Behm-Ansmant I, Rehwinkel J, Doerks T, Stark A, Bork P, Izaurralde E. 2006a. mRNA degradation by miRNAs and GW182 requires both CCR4:NOT deadenylase and DCP1:DCP2 decapping complexes. Genes Dev 20: 1885-1898.

Behm-Ansmant I, Rehwinkel J, Izaurralde E. 2006b. MicroRNAs silence gene expression by repressing protein expression and/or by promoting mRNA decay. Cold Spring Harb Symp Quant Biol 71: 523-530. 
Bernstein E, Caudy AA, Hammond SM, Hannon GJ. 2001 Role for a bidentate ribonuclease in the initiation step of RNA interference. Nature 409: 363-366.

Bethune J, Artus-Revel CG, Filipowicz W. 2012. Kinetic analysis reveals successive steps leading to miRNA-mediated silencing in mammalian cells. EMBO Rep 13: 716723.

Bhattacharyya SN, Habermacher R, Martine U, Closs EI, Filipowicz W. 2006. Relief of microRNA-mediated translational repression in human cells subjected to stress. Cell 125: 1111-1124.

Boland A, Huntzinger E, Schmidt S, Izaurralde E, Weichenrieder O. 2011. Crystal structure of the MID-PIWI lobe of a eukaryotic Argonaute protein. Proc Natl Acad Sci 108: 10466-10471.

Bouasker S, Simard MJ. 2012. The slicing activity of miRNAspecific Argonautes is essential for the miRNA pathway in C. elegans. Nucleic Acids Res 40: 10452-10462.

Braun JE, Huntzinger E, Fauser M, Izaurralde E. 2011. GW182 proteins directly recruit cytoplasmic deadenylase complexes to miRNA targets. Mol Cell 44: 120-133.

Brennecke J, Stark A, Russell RB, Cohen SM. 2005. Principles of microRNA-target recognition. PLoS Biol 3: e85.

Broderick JA, Salomon WE, Ryder SP, Aronin N, Zamore PD. 2011. Argonaute protein identity and pairing geometry determine cooperativity in mammalian RNA silencing. Rna 17: 1858-1869.

Broughton JP, Lovci MT, Huang JL, Yeo GW, Pasquinelli AE. 2016. Pairing beyond the seed supports microRNA targeting specificity. Mol Cell 64: 320-333.

Calin GA, Croce CM. 2006. MicroRNA-cancer connection The beginning of a new tale. Cancer Res 66: 7390-7394.

Carmell MA, Hannon GJ. 2004. RNase III enzymes and the initiation of gene silencing. Nat Struct Mol Biol 11: 214218.

Chandradoss SD, Schirle NT, Szczepaniak M, MacRae IJ, Joo C. 2015. A dynamic search process underlies microRNA targeting. Cell 162: 96-107.

Chapat C, Jafarnejad SM, Matta-Camacho E, Hesketh GG, Gelbart IA, Attig J, Gkogkas CG, Alain T, Stern-Ginossar N, Fabian MR, et al. 2017. Cap-binding protein 4EHP effects translation silencing by microRNAs. Proc Natl Acad Sci 114: 5425-5430.

Chekulaeva M, Mathys H, Zipprich JT, Attig J, Colic M, Parker R, Filipowicz W. 2011. miRNA repression involves GW182-mediated recruitment of CCR4-NOT through conserved W-containing motifs. Nat Struct Mol Biol 18: 1218-1226.

Chen S, Gao G. 2017. MicroRNAs recruit eIF4E2 to repress translation of target mRNAs. Protein Cell 8: 750-761.

Chen K, Rajewsky N. 2006. Deep conservation of microRNA-target relationships and $3^{\prime}$ UTR motifs in vertebrates, flies, and nematodes. Cold Spring Harb Symp Quant Biol 71: 149-156.

Chen K, Rajewsky N. 2007. The evolution of gene regulation by transcription factors and microRNAs. Nat Rev Genet 8: 93-103.

Chen CY, Zheng D, Xia Z, Shyu AB. 2009. Ago-TNRC6 triggers microRNA-mediated decay by promoting two deadenylation steps. Nat Struct Mol Biol 16: 1160-1166.
Chen Y, Boland A, Kuzuoğlu-Öztürk D, Bawankar P, Loh B, Chang CT, Weichenrieder O, Izaurralde E. 2014. A DDX6-CNOT1 complex and $\mathrm{W}$-binding pockets in CNOT9 reveal direct links between miRNA target recognition and silencing. Mol Cell 54: 737-750.

Cho PF, Poulin F, Cho-Park YA, Cho-Park IB, Chicoine JD, Lasko P, Sonenberg N. 2005. A new paradigm for translational control: Inhibition via $5^{\prime}-3^{\prime}$ mRNA tethering by Bicoid and the eIF4E cognate 4EHP. Cell 121: 411-423.

Christie M, Boland A, Huntzinger E, Weichenrieder O, Izaurralde E. 2013. Structure of the PAN3 pseudokinase reveals the basis for interactions with the PAN2 deadenylase and the GW182 proteins. Mol Cell 51: 360-373.

Chu CY, Rana TM. 2006. Translation repression in human cells by microRNA-induced gene silencing requires RCK/ p54. PLoS Biol 4: e210.

Cooke A, Prigge A, Wickens M. 2010. Translational repression by deadenylases. J Biol Chem 285: 28506-28513.

Croce CM, Calin GA. 2005. miRNAs, cancer, and stem cell division. Cell 122: 6-7.

Czech B, Hannon GJ. 2011. Small RNA sorting: Matchmaking for Argonautes. Nat Rev Genet 12: 19-31.

Czech B, Zhou R, Erlich Y, Brennecke J, Binari R, Villalta C, Gordon A, Perrimon N, Hannon GJ. 2009. Hierarchical rules for Argonaute loading in Drosophila. Mol Cell 36: 445-456.

Derry MC, Yanagiya A, Martineau Y, Sonenberg N. 2006. Regulation of poly(A)-binding protein through PABPinteracting proteins. Cold Spring Harb Symp Quant Biol 71: 537-543.

Djuranovic S, Nahvi A, Green R. 2012. miRNA-mediated gene silencing by translational repression followed by mRNA deadenylation and decay. Science 336: 237-240.

Dostie J, Ferraiuolo M, Pause A, Adam SA, Sonenberg N. 2000. A novel shuttling protein, $4 \mathrm{E}-\mathrm{T}$, mediates the nuclear import of the mRNA $5^{\prime}$ cap-binding protein, eIF4E. EMBO J 19: 3142-3156.

Ecsedi M, Rausch M, Grosshans H. 2015. The let-7 microRNA directs vulval development through a single target. Dev Cell 32: 335-344.

Eichhorn SW, Guo H, McGeary SE, Rodriguez-Mias RA, Shin C, Baek D, Hsu SH, Ghoshal K, Villen J, Bartel DP. 2014. mRNA destabilization is the dominant effect of mammalian microRNAs by the time substantial repression ensues. Mol Cell 56: 104-115.

Elcheva I, Goswami S, Noubissi FK, Spiegelman VS. 2009. CRD-BP protects the coding region of $\beta \operatorname{TrCP} 1 \mathrm{mRNA}$ from miR-183-mediated degradation. Mol Cell 35: 240246.

Elfakess R, Sinvani H, Haimov O, Svitkin Y, Sonenberg N, Dikstein R. 2011. Unique translation initiation of mRNAs-containing TISU element. Nucleic Acids Res 39: 7598-7609.

Elkayam E, Kuhn CD, Tocilj A, Haase AD, Greene EM, Hannon GJ, Joshua-Tor L. 2012. The structure of human argonaute-2 in complex with miR-20a. Cell 150: 100-110.

Elkayam E, Faehnle CR, Morales M, Sun J, Li H, Joshua-Tor L. 2017. Multivalent recruitment of human Argonaute by GW182. Mol Cell 67: 646-658.e643.

El-Shami M, Pontier D, Lahmy S, Braun L, Picart C, Vega D, Hakimi MA, Jacobsen SE, Cooke R, Lagrange T. 2007. 
Reiterated WG/GW motifs form functionally and evolutionarily conserved ARGONAUTE-binding platforms in RNAi-related components. Genes Dev 21: 2539-2544.

Emde A, Hornstein E. 2014. miRNAs at the interface of cellular stress and disease. EMBO J 33: 1428-1437.

Eulalio A, Rehwinkel J, Stricker M, Huntzinger E, Yang SF, Doerks T, Dorner S, Bork P, Boutros M, Izaurralde E. 2007. Target-specific requirements for enhancers of decapping in miRNA-mediated gene silencing. Genes Dev 21: $2558-2570$.

Eulalio A, Huntzinger E, Izaurralde E. 2008. GW182 interaction with Argonaute is essential for miRNA-mediated translational repression and mRNA decay. Nat Struct Mol Biol 15: 346-353.

Eulalio A, Helms S, Fritzsch C, Fauser M, Izaurralde E. 2009a. A C-terminal silencing domain in GW182 is essential for miRNA function. RNA 15: 1067-1077.

Eulalio A, Tritschler F, Buttner R, Weichenrieder O, Izaurralde E, Truffault V. 2009b. The RRM domain in GW182 proteins contributes to miRNA-mediated gene silencing. Nucleic Acids Res 37: 2974-2983.

Fabian MR, Mathonnet G, Sundermeier T, Mathys H, Zipprich JT, Svitkin YV, Rivas F, Jinek M, Wohlschlegel J, Doudna JA, et al. 2009. Mammalian miRNA RISC recruits CAF1 and PABP to affect PABP-dependent deadenylation. Mol Cell 35: 868-880.

Fabian MR, Cieplak MK, Frank F, Morita M, Green J, Srikumar T, Nagar B, Yamamoto T, Raught B, Duchaine TF, et al. 2011. miRNA-mediated deadenylation is orchestrated by GW182 through two conserved motifs that interact with CCR4-NOT. Nat Struct Mol Biol 18: 1211-1217.

Fang Z, Rajewsky N. 2011. The impact of miRNA target sites in coding sequences and in $3^{\prime}$ UTRs. PLoS ONE 6: e18067.

Farh KK, Grimson A, Jan C, Lewis BP, Johnston WK, Lim LP, Burge CB, Bartel DP. 2005. The widespread impact of mammalian microRNAs on mRNA repression and evolution. Science 310: 1817-1821.

Ferraiuolo MA, Basak S, Dostie J, Murray EL, Schoenberg DR, Sonenberg N. 2005. A role for the eIF4E-binding protein $4 \mathrm{E}-\mathrm{T}$ in P-body formation and mRNA decay. $J$ Cell Biol 170: 913-924.

Flamand MN, Wu E, Vashisht A, Jannot G, Keiper BD, Simard MJ, Wohlschlegel J, Duchaine TF. 2016. Poly (A)-binding proteins are required for microRNA-mediated silencing and to promote target deadenylation in C. elegans. Nucleic Acids Res 44: 5924-5935.

Flamand MN, Gan HH, Mayya VK, Gunsalus KC, Duchaine TF. 2017. A non-canonical site reveals the cooperative mechanisms of microRNA-mediated silencing. Nucleic Acids Res 45: 7212-7225.

Frank F, Fabian MR, Stepinski J, Jemielity J, Darzynkiewicz E, Sonenberg N, Nagar B. 2011. Structural analysis of 5'mRNA-cap interactions with the human AGO2 MID domain. EMBO Rep 12: 415-420.

Friedman RC, Farh KK, Burge CB, Bartel DP. 2009. Most mammalian mRNAs are conserved targets of microRNAs. Genome Res 19: 92-105.

Fukao A, Mishima Y, Takizawa N, Oka S, Imataka H, Pelletier J, Sonenberg N, Thoma C, Fujiwara T. 2014. MicroRNAs trigger dissociation of eIF4AI and eIF4AII from target mRNAs in humans. Mol Cell 56: 79-89.
Fukaya T, Tomari Y. 2011. PABP is not essential for microRNA-mediated translational repression and deadenylation in vitro. $Е M B O J$ 30: 4998-5009.

Fukaya T, Iwakawa HO, Tomari Y. 2014. MicroRNAs block assembly of eIF4F translation initiation complex in Drosophila. Mol Cell 56: 67-78.

Galicia-Vazquez G, Chu J, Pelletier J. 2015. eIF4AII is dispensable for miRNA-mediated gene silencing. RNA 21: 1826-1833.

Gingras AC, Raught B, Sonenberg N. 1999. eIF4 initiation factors: Effectors of mRNA recruitment to ribosomes and regulators of translation. Annu Rev Biochem 68: 913-963.

Giraldez AJ, Cinalli RM, Glasner ME, Enright AJ, Thomson JM, Baskerville S, Hammond SM, Bartel DP, Schier AF. 2005. MicroRNAs regulate brain morphogenesis in zebrafish. Science 308: 833-838.

Giraldez AJ, Mishima Y, Rihel J, Grocock RJ, Van Dongen S, Inoue K, Enright AJ, Schier AF. 2006. Zebrafish MiR-430 promotes deadenylation and clearance of maternal mRNAs. Science 312: 75-79.

Giri R, Carthew RW. 2014. MicroRNAs suppress cellular phenotypic heterogeneity. Cell Cycle 13: 1517-1518.

Gregory RI, Chendrimada TP, Cooch N, Shiekhattar R. 2005. Human RISC couples microRNA biogenesis and posttranscriptional gene silencing. Cell 123: 631-640.

Grimson A, Farh KK, Johnston WK, Garrett-Engele P, Lim LP, Bartel DP. 2007. MicroRNA targeting specificity in mammals: Determinants beyond seed pairing. Mol Cell 27: 91-105.

Grishok A, Pasquinelli AE, Conte D, Li N, Parrish S, Ha I, Baillie DL, Fire A, Ruvkun G, Mello CC. 2001. Genes and mechanisms related to RNA interference regulate expression of the small temporal RNAs that control C. elegans developmental timing. Cell 106: 23-34.

Guo H, Ingolia NT, Weissman JS, Bartel DP. 2010. Mammalian microRNAs predominantly act to decrease target mRNA levels. Nature 466: 835-840.

Ha M, Kim VN. 2014. Regulation of microRNA biogenesis. Nat Rev Mol Cell Biol 15: 509-524.

Haas G, Braun JE, Igreja C, Tritschler F, Nishihara T, Izaurralde E. 2010. HPat provides a link between deadenylation and decapping in metazoa. J Cell Biol 189: 289-302.

Haley B, Zamore PD. 2004. Kinetic analysis of the RNAi enzyme complex. Nat Struct Mol Biol 11: 599-606.

Hammond SM, Bernstein E, Beach D, Hannon GJ. 2000. An RNA-directed nuclease mediates post-transcriptional gene silencing in Drosophila cells. Nature 404: 293-296.

Hammond SM, Boettcher S, Caudy AA, Kobayashi R, Hannon GJ. 2001. Argonaute2, a link between genetic and biochemical analyses of RNAi. Science 293: 1146-1150.

He L, Thomson JM, Hemann MT, Hernando-Monge E, Mu D, Goodson S, Powers S, Cordon-Cardo C, Lowe SW, Hannon GJ, et al. 2005. A microRNA polycistron as a potential human oncogene. Nature 435: 828-833.

* Heck AM, Wilusz J. 2018. The interplay between the RNA decay and translation machinery in eukaryotes. Cold Spring Harb Perspect Biol 10.1101/cshperspect.a032839.

Huang J, Liang Z, Yang B, Tian H, Ma J, Zhang H. 2007. Derepression of microRNA-mediated protein translation inhibition by apolipoprotein B mRNA-editing enzyme 
catalytic polypeptide-like 3G (APOBEC3G) and its family members. J Biol Chem 282: 33632-33640.

Humphreys DT, Westman BJ, Martin DI, Preiss T. 2005. MicroRNAs control translation initiation by inhibiting eukaryotic initiation factor $4 \mathrm{E} / \mathrm{cap}$ and poly(A) tail function. Proc Natl Acad Sci 102: 16961-16966.

Huntzinger E, Braun JE, Heimstadt S, Zekri L, Izaurralde E. 2010. Two PABPC1-binding sites in GW182 proteins promote miRNA-mediated gene silencing. $E M B O J$ 29: 4146-4160.

Hutvágner G, McLachlan J, Pasquinelli AE, Balint E, Tuschl T, Zamore PD. 2001. A cellular function for the RNAinterference enzyme Dicer in the maturation of the let-7 small temporal RNA. Science 293: 834-838.

Inukai S, Pincus Z, de Lencastre A, Slack FJ. 2018. A microRNA feedback loop regulates global microRNA abundance during aging. RNA 24: 159-172.

Iorio MV, Croce CM. 2013. MicroRNA profiling in ovarian cancer. Methods Mol Biol 1049: 187-197.

Iorio MV, Croce CM. 2017. MicroRNA dysregulation in cancer: Diagnostics, monitoring and therapeutics. A comprehensive review. EMBO Mol Med 9: 852.

Jafarifar F, Yao P, Eswarappa SM, Fox PL. 2011. Repression of VEGFA by CA-rich element-binding microRNAs is modulated by hnRNP L. EMBO J 30: 1324-1334.

Jafarnejad SM, Chapat C, Matta-Camacho E, Gelbart IA, Hesketh GG, Arguello M, Garzia A, Kim SH, Attig J, Shapiro M, et al. 2018. Translational control of ERK signaling through miRNA/4EHP-directed silencing. eLife 7: e35034.

Jee D, Yang JS, Park SM, Farmer DT, Wen J, Chou T, Chow A, McManus MT, Kharas MG, Lai EC. 2018. Dual strategies for argonaute2-mediated biogenesis of erythroid miRNAs underlie conserved requirements for slicing in mammals. Mol Cell 69: 265-278.e266.

Jens M, Rajewsky N. 2015. Competition between target sites of regulators shapes post-transcriptional gene regulation. Nat Rev Genet 16: 113-126.

Jinek M, Fabian MR, Coyle SM, Sonenberg N, Doudna JA. 2010. Structural insights into the human GW182-PABC interaction in microRNA-mediated deadenylation. Nat Struct Mol Biol 17: 238-240.

Jonas S, Izaurralde E. 2013. The role of disordered protein regions in the assembly of decapping complexes and RNP granules. Genes Dev 27: 2628-2641.

Kahvejian A, Svitkin YV, Sukarieh R, M'Boutchou MN, Sonenberg N. 2005. Mammalian poly(A)-binding protein is a eukaryotic translation initiation factor, which acts via multiple mechanisms. Genes Dev 19: 104-113.

Kamenska A, Lu WT, Kubacka D, Broomhead H, Minshall N, Bushell M, Standart N. 2014. Human 4E-T represses translation of bound mRNAs and enhances microRNAmediated silencing. Nucleic Acids Res 42: 3298-3313.

Kamenska A, Simpson C, Vindry C, Broomhead H, Benard M, Ernoult-Lange M, Lee BP, Harries LW, Weil D, Standart N. 2016. The DDX6-4E-T interaction mediates translational repression and P-body assembly. Nucleic Acids Res 44: 6318-6334.

Kedde M, Strasser MJ, Boldajipour B, Oude Vrielink JA, Slanchev K, le Sage C, Nagel R, Voorhoeve PM, van Duijse J, Orom UA, et al. 2007. RNA-binding protein
Dnd1 inhibits microRNA access to target mRNA. Cell 131: 1273-1286.

Kedde M, van Kouwenhove M, Zwart W, Oude Vrielink JA, Elkon R, Agami R. 2010. A Pumilio-induced RNA structure switch in p27-3' UTR controls miR-221 and miR222 accessibility. Nat Cell Biol 12: 1014-1020.

Ketting RF, Fischer SE, Bernstein E, Sijen T, Hannon GJ, Plasterk RH. 2001. Dicer functions in RNA interference and in synthesis of small RNA involved in developmental timing in C. elegans. Genes Dev 15: 2654-2659.

Khaleghpour K, Svitkin YV, Craig AW, DeMaria CT, Deo RC, Burley SK, Sonenberg N. 2001. Translational repression by a novel partner of human poly(A) binding protein, Paip2. Mol Cell 7: 205-216.

Kidner CA, Martienssen RA. 2004. Spatially restricted microRNA directs leaf polarity through ARGONAUTE1. Nature 428: 81-84.

Klum SM, Chandradoss SD, Schirle NT, Joo C, MacRae IJ. 2017. Helix-7 in Argonaute2 shapes the microRNA seed region for rapid target recognition. EMBO J 37: 75-88.

Knight SW, Bass BL. 2001. A role for the RNase III enzyme DCR-1 in RNA interference and germ line development in Caenorhabditis elegans. Science 293: 2269-2271.

Kobayashi H, Tomari Y. 2016. RISC assembly: Coordination between small RNAs and Argonaute proteins. Biochim Biophys Acta 1859: 71-81.

Kozlov G, Safaee N, Rosenauer A, Gehring K. 2010. Structural basis of binding of P-body-associated proteins GW182 and ataxin-2 by the Mlle domain of poly(A)binding protein. J Biol Chem 285: 13599-13606.

Krek A, Grun D, Poy MN, Wolf R, Rosenberg L, Epstein EJ, MacMenamin P, da Piedade I, Gunsalus KC, Stoffel M, et al. 2005. Combinatorial microRNA target predictions. Nat Genet 37: 495-500.

Kundu P, Fabian MR, Sonenberg N, Bhattacharyya SN, Filipowicz W. 2012. HuR protein attenuates miRNA-mediated repression by promoting miRISC dissociation from the target RNA. Nucleic Acids Res 40: 5088-5100.

Kuzuoğlu-Öztürk D, Huntzinger E, Schmidt S, Izaurralde E. 2012. The Caenorhabditis elegans GW182 protein AIN-1 interacts with PAB-1 and subunits of the PAN2-PAN3 and CCR4-NOT deadenylase complexes. Nucleic Acids Res 40: 5651-5665.

Kuzuoğlu-Öztürk D, Bhandari D, Huntzinger E, Fauser M, Helms S, Izaurralde E. 2016. miRISC and the CCR4-NOT complex silence mRNA targets independently of $43 \mathrm{~S}$ ribosomal scanning. EMBO J 35: 1186-1203.

* Kwan T, Thompson SR. Noncanonical translation initiation in eukaryotes. Cold Spring Harb Perspect Biol 10.1101/ cshperspect.a032672.

Lagos-Quintana M, Rauhut R, Lendeckel W, Tuschl T. 2001. Identification of novel genes coding for small expressed RNAs. Science 294: 853-858.

Lagos-Quintana M, Rauhut R, Meyer J, Borkhardt A, Tuschl T. 2003. New microRNAs from mouse and human. RNA 9: 175-179.

Lai EC. 2002. Micro RNAs are complementary to $3^{\prime}$ UTR sequence motifs that mediate negative post-transcriptional regulation. Nat Genet 30: 363-364.

Lall S, Grun D, Krek A, Chen K, Wang YL, Dewey CN, Sood P, Colombo T, Bray N, Macmenamin P, et al. 2006. A 
genome-wide map of conserved microRNA targets in C. elegans. Curr Biol 16: 460-471.

Lau NC, Lim LP, Weinstein EG, Bartel DP. 2001. An abundant class of tiny RNAs with probable regulatory roles in Caenorhabditis elegans. Science 294: 858-862.

Lee RC, Ambros V. 2001. An extensive class of small RNAs in Caenorhabditis elegans. Science 294: 862-864.

Lee RC, Feinbaum RL, Ambros V. 1993. The C. elegans heterochronic gene lin-4 encodes small RNAs with antisense complementarity to lin-14. Cell 75: 843-854.

Lee Y, Ahn C, Han J, Choi H, Kim J, Yim J, Lee J, Provost P, Radmark O, Kim S, et al. 2003. The nuclear RNase III Drosha initiates microRNA processing. Nature 425: 415419.

Lewis BP, Shih IH, Jones-Rhoades MW, Bartel DP, Burge CB. 2003. Prediction of mammalian microRNA targets. Cell 115: 787-798.

Lewis BP, Burge CB, Bartel DP. 2005. Conserved seed pairing, often flanked by adenosines, indicates that thousands of human genes are microRNA targets. Cell 120: 15-20.

Li X, Cassidy JJ, Reinke CA, Fischboeck S, Carthew RW. 2009. A microRNA imparts robustness against environmental fluctuation during development. Cell 137: 273 282.

Lian SL, Li S, Abadal GX, Pauley BA, Fritzler MJ, Chan EK. 2009. The C-terminal half of human Ago2 binds to multiple GW-rich regions of GW182 and requires GW182 to mediate silencing. RNA 15: 804-813.

Lim LP, Glasner ME, Yekta S, Burge CB, Bartel DP. 2003a. Vertebrate microRNA genes. Science 299: 1540.

Lim LP, Lau NC, Weinstein EG, Abdelhakim A, Yekta S, Rhoades MW, Burge CB, Bartel DP. 2003b. The microRNAs of Caenorhabditis elegans. Genes Dev 17: 9911008.

Lim LP, Lau NC, Garrett-Engele P, Grimson A, Schelter JM, Castle J, Bartel DP, Linsley PS, Johnson JM. 2005. Microarray analysis shows that some microRNAs downregulate large numbers of target mRNAs. Nature 433: 769-773.

Lingel A, Simon B, Izaurralde E, Sattler M. 2003. Structure and nucleic-acid binding of the Drosophila Argonaute 2 PAZ domain. Nature 426: 465-469.

Lingel A, Simon B, Izaurralde E, Sattler M. 2004. Nucleic acid $3^{\prime}$-end recognition by the Argonaute2 PAZ domain. Nat Struct Mol Biol 11: 576-577.

Liu J, Carmell MA, Rivas FV, Marsden CG, Thomson JM, Song JJ, Hammond SM, Joshua-Tor L, Hannon GJ. 2004. Argonaute2 is the catalytic engine of mammalian RNAi. Science 305: 1437-1441.

Ma JB, Ye K, Patel DJ. 2004. Structural basis for overhangspecific small interfering RNA recognition by the PAZ domain. Nature 429: 318-322.

Maniataki E, Mourelatos Z. 2005. A human, ATP-independent, RISC assembly machine fueled by pre-miRNA Genes Dev 19: 2979-2990.

Mann M, Barad O, Agami R, Geiger B, Hornstein E. 2010. miRNA-based mechanism for the commitment of multipotent progenitors to a single cellular fate. Proc Natl Acad Sci 107: 15804-15809.

Mathonnet G, Fabian MR, Svitkin YV, Parsyan A, Huck L, Murata T, Biffo S, Merrick WC, Darzynkiewicz E, Pillai RS, et al. 2007. MicroRNA inhibition of translation initi-
Mechanisms of miRNA-Mediated Gene Silencing

ation in vitro by targeting the cap-binding complex eIF4F. Science 317: 1764-1767.

Mathys H, Basquin J, Ozgur S, Czarnocki-Cieciura M, Bonneau F, Aartse A, Dziembowski A, Nowotny M, Conti E, Filipowicz W. 2014. Structural and biochemical insights to the role of the CCR4-NOT complex and DDX6 ATPase in microRNA repression. Mol Cell 54: 751-765.

Matranga C, Tomari Y, Shin C, Bartel DP, Zamore PD. 2005. Passenger-strand cleavage facilitates assembly of siRNA into Ago2-containing RNAi enzyme complexes. Cell 123: 607-620.

Mauri M, Kirchner M, Aharoni R, Ciolli Mattioli C, van den Bruck D, Gutkovitch N, Modepalli V, Selbach M, Moran Y, Chekulaeva M. 2017. Conservation of miRNA-mediated silencing mechanisms across 600 million years of animal evolution. Nucleic Acids Res 45: 938-950.

Mauxion F, Chen CY, Seraphin B, Shyu AB. 2009. BTG/TOB factors impact deadenylases. Trends Biochem Sci 34: 640647.

Mayr C. 2017. Regulation by $3^{\prime}$-untranslated regions. Annu Rev Genet 51: 171-194.

Mayya VK, Duchaine TF. 2015. On the availability of microRNA-induced silencing complexes, saturation of microRNA-binding sites and stoichiometry. Nucleic Acids Res 43: 7556-7565.

Meijer HA, Kong YW, Lu WT, Wilczynska A, Spriggs RV, Robinson SW, Godfrey JD, Willis AE, Bushell M. 2013. Translational repression and eIF4A2 activity are critical for microRNA-mediated gene regulation. Science 340: $82-85$.

* Merrick WC, Pavitt GD. 2018. Protein synthesis initiation in eukaryotic cells. Cold Spring Harb Perspect Biol 10.1101/ cshperspect.a033092.

Mishima Y, Fukao A, Kishimoto T, Sakamoto H, Fujiwara T, Inoue K. 2012. Translational inhibition by deadenylationindependent mechanisms is central to microRNA-mediated silencing in zebrafish. Proc Natl Acad Sci 109: 11041109.

Miyoshi K, Tsukumo H, Nagami T, Siomi H, Siomi MC. 2005. Slicer function of Drosophila Argonautes and its involvement in RISC formation. Genes Dev 19: 28372848.

Moretti F, Kaiser C, Zdanowicz-Specht A, Hentze MW. 2012. PABP and the poly(A) tail augment microRNA repression by facilitated miRISC binding. Nat Struct Mol Biol 19: 603-608.

Morita M, Ler LW, Fabian MR, Siddiqui N, Mullin M, Henderson VC, Alain T, Fonseca BD, Karashchuk G, Bennett CF, et al. 2012. A novel 4EHP-GIGYF2 translational repressor complex is essential for mammalian development. Mol Cell Biol 32: 3585-3593.

Nakanishi K, Weinberg DE, Bartel DP, Patel DJ. 2012. Structure of yeast Argonaute with guide RNA. Nature 486 368-374.

Nishihara T, Zekri L, Braun JE, Izaurralde E. 2013. miRISC recruits decapping factors to miRNA targets to enhance their degradation. Nucleic Acids Res 41: 8692-8705.

Nishimura T, Padamsi Z, Fakim H, Milette S, Dunham WH, Gingras AC, Fabian MR. 2015. The eIF4E-binding protein $4 \mathrm{E}-\mathrm{T}$ is a component of the mRNA decay machinery 
that bridges the $5^{\prime}$ and $3^{\prime}$ termini of target mRNAs. Cell Rep 11: 1425-1436.

Nottrott S, Simard MJ, Richter JD. 2006. Human let-7a miRNA blocks protein production on actively translating polyribosomes. Nat Struct Mol Biol 13: 1108-1114.

Olsen PH, Ambros V. 1999. The lin-4 regulatory RNA controls developmental timing in Caenorhabditis elegans by blocking LIN-14 protein synthesis after the initiation of translation. Dev Biol 216: 671-680.

Ozgur S, Chekulaeva M, Stoecklin G. 2010. Human Pat1b connects deadenylation with mRNA decapping and controls the assembly of processing bodies. Mol Cell Biol 30: 4308-4323.

Ozgur S, Basquin J, Kamenska A, Filipowicz W, Standart N, Conti E. 2015. Structure of a human 4E-T/DDX6/ CNOT1 complex reveals the different interplay of DDX6-binding proteins with the CCR4-NOT complex. Cell Rep 13: 703-711.

Park JH, Shin C. 2015. Slicer-independent mechanism drives small-RNA strand separation during human RISC assembly. Nucleic Acids Res 43: 9418-9433.

Pasquinelli AE, Reinhart BJ, Slack F, Martindale MQ, Kuroda MI, Maller B, Hayward DC, Ball EE, Degnan B, Muller P, et al. 2000. Conservation of the sequence and temporal expression of let-7 heterochronic regulatory RNA. Nature 408: 86-89.

Pelaez N, Carthew RW. 2012. Biological robustness and the role of microRNAs: A network perspective. Curr Top Dev Biol 99: 237-255.

Peter D, Weber R, Sandmeir F, Wohlbold L, Helms S, Bawankar P, Valkov E, Igreja C, Izaurralde E. 2017. GIGYF1/ 2 proteins use auxiliary sequences to selectively bind to 4EHP and repress target mRNA expression. Genes Dev 31: 1147-1161.

Petersen CP, Bordeleau ME, Pelletier J, Sharp PA. 2006 Short RNAs repress translation after initiation in mammalian cells. Mol Cell 21: 533-542.

Pfaff J, Hennig J, Herzog F, Aebersold R, Sattler M, Niessing D, Meister G. 2013. Structural features of ArgonauteGW182 protein interactions. Proc Natl Acad Sci 110: E3770-E3779.

Pillai RS, Bhattacharyya SN, Artus CG, Zoller T, Cougot N, Basyuk E, Bertrand E, Filipowicz W. 2005. Inhibition of translational initiation by Let-7 microRNA in human cells. Science 309: 1573-1576.

Posadas DM, Carthew RW. 2014. MicroRNAs and their roles in developmental canalization. Curr Opin Genet Dev 27: 1-6.

Rabani M, Pieper L, Chew GL, Schier AF. 2017. A massively parallel reporter assay of $3^{\prime}$ UTR sequences identifies in vivo rules for mRNA degradation. Mol Cell 68: 10831094.e1085.

Reinhart BJ, Slack FJ, Basson M, Pasquinelli AE, Bettinger JC, Rougvie AE, Horvitz HR, Ruvkun G. 2000. The 21nucleotide let-7 RNA regulates developmental timing in Caenorhabditis elegans. Nature 403: 901-906.

Ricci EP, Limousin T, Soto-Rifo R, Rubilar PS, Decimo D, Ohlmann T. 2013. miRNA repression of translation in vitro takes place during $43 \mathrm{~S}$ ribosomal scanning. Nucleic Acids Res 41: 586-598.
Rissland OS, Subtelny AO, Wang M, Lugowski A, Nicholson B, Laver JD, Sidhu SS, Smibert CA, Lipshitz HD, Bartel DP. 2017. The influence of microRNAs and poly(A) tail length on endogenous mRNA-protein complexes. Genome Biol 18: 211.

Rom E, Kim HC, Gingras AC, Marcotrigiano J, Favre D, Olsen H, Burley SK, Sonenberg N. 1998. Cloning and characterization of 4EHP, a novel mammalian eIF4E-related cap-binding protein. J Biol Chem 273: 13104-13109.

Romano G, Veneziano D, Acunzo M, Croce CM. 2017. Small non-coding RNA and cancer. Carcinogenesis 38: 485491.

Rouya C, Siddiqui N, Morita M, Duchaine TF, Fabian MR, Sonenberg N. 2014. Human DDX6 effects miRNA-mediated gene silencing via direct binding to CNOT1. RNA 20: 1398-1409.

Roy G, De Crescenzo G, Khaleghpour K, Kahvejian A, O'Connor-McCourt M, Sonenberg N. 2002. Paip1 interacts with poly(A) binding protein through two independent binding motifs. Mol Cell Biol 22: 3769-3782.

Saetrom P, Heale BS, Snove O Jr, Aagaard L, Alluin J, Rossi JJ. 2007. Distance constraints between microRNA target sites dictate efficacy and cooperativity. Nucleic Acids Res 35: 2333-2342.

Salomon WE, Jolly SM, Moore MJ, Zamore PD, Serebrov V. 2016. Single-molecule imaging reveals that Argonaute reshapes the binding properties of its nucleic acid guides. Cell 166: 517-520.

Schirle NT, MacRae IJ. 2012. The crystal structure of human Argonaute2. Science 336: 1037-1040.

Schirle NT, Sheu-Gruttadauria J, MacRae IJ. 2014. Structural basis for microRNA targeting. Science 346: 608-613.

Schirle NT, Sheu-Gruttadauria J, Chandradoss SD, Joo C, MacRae IJ. 2015. Water-mediated recognition of t1-adenosine anchors Argonaute2 to microRNA targets. eLife 4: e07646.

Schopp IM, Amaya Ramirez CC, Debeljak J, Kreibich E, Skribbe M, Wild K, Bethune J. 2017. Split-BioID a conditional proteomics approach to monitor the composition of spatiotemporally defined protein complexes. Nat Commun 8: 15690.

Selbach M, Schwanhausser B, Thierfelder N, Fang Z, Khanin R, Rajewsky N. 2008. Widespread changes in protein synthesis induced by microRNAs. Nature 455: 58-63.

Sharif H, Ozgur S, Sharma K, Basquin C, Urlaub H, Conti E. 2013. Structural analysis of the yeast Dhh1-Pat 1 complex reveals how Dhh1 engages Pat1, Edc3 and RNA in mutually exclusive interactions. Nucleic Acids Res 41: 83778390.

Sheu-Gruttadauria J, MacRae IJ. 2017. Structural foundations of RNA silencing by Argonaute. J Mol Biol 429: 2619-2639.

Siddiqui N, Osborne MJ, Gallie DR, Gehring K. 2007. Solution structure of the PABC domain from wheat poly(A)-binding protein: An insight into RNA metabolic and translational control in plants. Biochemistry 46: 4221-4231.

Smith RW, Blee TK, Gray NK. 2014. Poly(A)-binding proteins are required for diverse biological processes in metazoans. Biochem Soc Trans 42: 1229-1237. 
Sonenberg N, Hinnebusch AG. 2009. Regulation of translation initiation in eukaryotes: Mechanisms and biological targets. Cell 136: 731-745.

Song JJ, Liu J, Tolia NH, Schneiderman J, Smith SK, Martienssen RA, Hannon GJ, Joshua-Tor L. 2003. The crystal structure of the Argonaute2 PAZ domain reveals an RNA binding motif in RNAi effector complexes. Nat Struct Biol 10: $1026-1032$.

Song JJ, Smith SK, Hannon GJ, Joshua-Tor L. 2004. Crystal structure of Argonaute and its implications for RISC slicer activity. Science 305: 1434-1437.

Stark A, Brennecke J, Bushati N, Russell RB, Cohen SM 2005. Animal microRNAs confer robustness to gene expression and have a significant impact on $3^{\prime}$ UTR evolution. Cell 123: 1133-1146.

Subtelny AO, Eichhorn SW, Chen GR, Sive H, Bartel DP. 2014. Poly(A)-tail profiling reveals an embryonic switch in translational control. Nature 508: 66-71.

Sun K, Lai EC. 2013. Adult-specific functions of animal microRNAs. Nat Rev Genet 14: 535-548.

Takeda Y, Mishima Y, Fujiwara T, Sakamoto H, Inoue K. 2009. DAZL relieves miRNA-mediated repression of germline mRNAs by controlling poly(A) tail length in zebrafish. PLoS ONE 4: e7513.

Takimoto K, Wakiyama M, Yokoyama S. 2009. Mammalian GW182 contains multiple Argonaute-binding sites and functions in microRNA-mediated translational repression. RNA 15: 1078-1089.

Thermann R, Hentze MW. 2007. Drosophila miR2 induces pseudo-polysomes and inhibits translation initiation. $\mathrm{Na}$ ture 447: 875-878.

Tritschler F, Braun JE, Eulalio A, Truffault V, Izaurralde E, Weichenrieder O. 2009. Structural basis for the mutually exclusive anchoring of $\mathrm{P}$ body components EDC3 and Tral to the DEAD box protein DDX6/Me31B. Mol Cell 33: 661-668.

Waghray S, Williams C, Coon JJ, Wickens M. 2015. Xenopus CAF1 requires NOT1-mediated interaction with $4 \mathrm{E}-\mathrm{T}$ to repress translation in vivo. RNA 21: 1335-1345.

Wakiyama M, Takimoto K, Ohara O, Yokoyama S. 2007. Let-7 microRNA-mediated mRNA deadenylation and translational repression in a mammalian cell-free system. Genes Dev 21: 1857-1862.

Wang Y, Juranek S, Li H, Sheng G, Tuschl T, Patel DJ. 2008a. Structure of an argonaute silencing complex with a seedcontaining guide DNA and target RNA duplex. Nature 456: 921-926.
Mechanisms of miRNA-Mediated Gene Silencing

Wang Y, Sheng G, Juranek S, Tuschl T, Patel DJ. 2008b Structure of the guide-strand-containing argonaute silencing complex. Nature 456: 209-213.

Wee LM, Flores-Jasso CF, Salomon WE, Zamore PD. 2012. Argonaute divides its RNA guide into domains with distinct functions and RNA-binding properties. Cell 151: 1055-1067.

Wolter JM, Le HH, Linse A, Godlove VA, Nguyen TD, Kotagama K, Lynch A, Rawls A, Mangone M. 2017. Evolutionary patterns of metazoan microRNAs reveal targeting principles in the let-7 and miR-10 families. Genome Res 27: 53-63.

Wu L, Fan J, Belasco JG. 2006. MicroRNAs direct rapid deadenylation of mRNA. Proc Natl Acad Sci 103: 40344039.

Wu E, Thivierge C, Flamand M, Mathonnet G, Vashisht AA, Wohlschlegel J, Fabian MR, Sonenberg N, Duchaine TF. 2010. Pervasive and cooperative deadenylation of $3^{\prime}$ UTRs by embryonic microRNA families. Mol Cell 40: 558-570.

Wu E, Vashisht AA, Chapat C, Flamand MN, Cohen E Sarov M, Tabach Y, Sonenberg N, Wohlschlegel J, Duchaine TF. 2017. A continuum of mRNP complexes in embryonic microRNA-mediated silencing. Nucleic Acids Res 45: 2081-2098.

Xin M, Olson EN, Bassel-Duby R. 2013. Mending broken hearts: Cardiac development as a basis for adult heart regeneration and repair. Nat Rev Mol Cell Biol 14: 529541.

Yan KS, Yan S, Farooq A, Han A, Zeng L, Zhou MM. 2003. Structure and conserved RNA binding of the PAZ domain. Nature 426: 468-474.

Yao B, Li S, Lian SL, Fritzler MJ, Chan EK. 2011. Mapping of Ago2-GW182 functional interactions. Methods Mol Biol 725: 45-62.

Yartseva V, Takacs CM, Vejnar CE, Lee MT, Giraldez AJ. 2017. RESA identifies mRNA-regulatory sequences at high resolution. Nat Methods 14: 201-207.

Zdanowicz A, Thermann R, Kowalska J, Jemielity J, Duncan K, Preiss T, Darzynkiewicz E, Hentze MW. 2009. Drosophila miR2 primarily targets the $\mathrm{m}^{7} \mathrm{GpppN}$ cap structure for translational repression. Mol Cell 35: 881-888.

Zekri L, Kuzuoğlu-Öztürk D, Izaurralde E. 2013. GW182 proteins cause PABP dissociation from silenced miRNA targets in the absence of deadenylation. EMBO J 32: 1052-1065. 


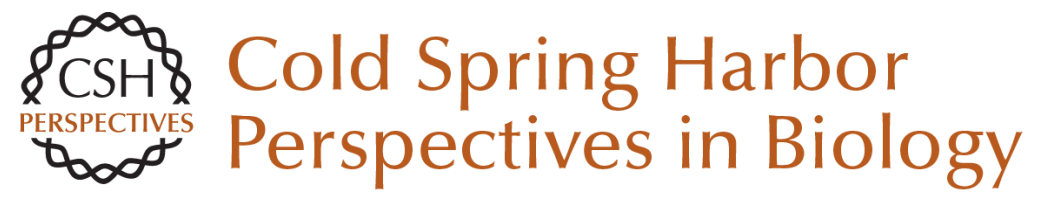

\section{Mechanistic Insights into MicroRNA-Mediated Gene Silencing}

Thomas F. Duchaine and Marc R. Fabian

Cold Spring Harb Perspect Biol 2019; doi: 10.1101/cshperspect.a032771 originally published online June 29, 2018

\section{Subject Collection Translation Mechanisms and Control}

Protein Synthesis and Translational Control: A Historical Perspective

Soroush Tahmasebi, Nahum Sonenberg, John W.B. Hershey, et al.

Translational Control in the Brain in Health and Disease

Wayne S. Sossin and Mauro Costa-Mattioli

Phosphorylation and Signal Transduction

Pathways in Translational Control Christopher G. Proud

Translational Control during Developmental Transitions

Felipe Karam Teixeira and Ruth Lehmann

Stress Granules and Processing Bodies in

Translational Control

Pavel Ivanov, Nancy Kedersha and Paul Anderson

Fluorescence Imaging Methods to Investigate

Translation in Single Cells

Jeetayu Biswas, Yang Liu, Robert H. Singer, et al.

Translational Control in Virus-Infected Cells Noam Stern-Ginossar, Sunnie R. Thompson, Michael B. Mathews, et al.

Nonsense-Mediated mRNA Decay Begins Where Translation Ends

Evangelos D. Karousis and Oliver Mühlemann
Principles of Translational Control John W.B. Hershey, Nahum Sonenberg and Michael B. Mathews

The Epitranscriptome in Translation Regulation Eyal Peer, Sharon Moshitch-Moshkovitz, Gideon Rechavi, et al.

Translational Control in Cancer Nathaniel Robichaud, Nahum Sonenberg, Davide Ruggero, et al.

Roles of Long Noncoding RNAs and Circular

RNAs in Translation Marina Chekulaeva and Nikolaus Rajewsky

Ribosome Profiling: Global Views of Translation Nicholas T. Ingolia, Jeffrey A. Hussmann and Jonathan S. Weissman

Noncanonical Translation Initiation in Eukaryotes Thaddaeus Kwan and Sunnie R. Thompson

Mechanistic Insights into MicroRNA-Mediated Gene Silencing Thomas F. Duchaine and Marc R. Fabian

Toward a Kinetic Understanding of Eukaryotic Translation Masaaki Sokabe and Christopher S. Fraser

For additional articles in this collection, see http://cshperspectives.cshlp.org/cgi/collection/

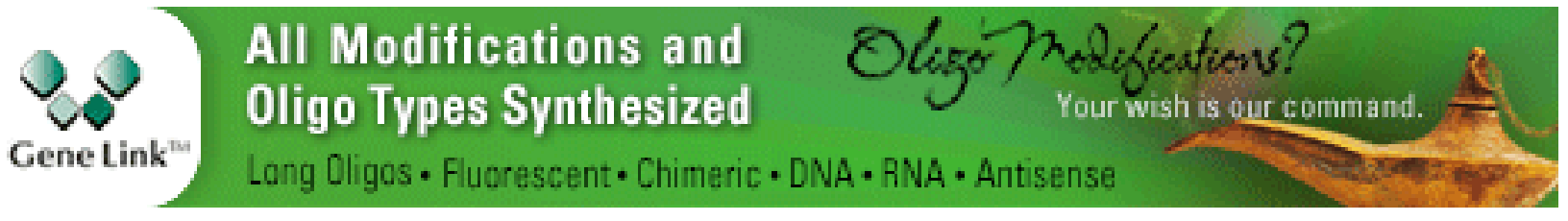

